\title{
Screening of Antiviral Components of Yinhuapinggan Granule and Protective Effects of Yinhuapinggan Granule on MDCK Cells with Influenza A/H1N1 Virus
}

\author{
Tianhang Chen, ${ }^{1}$ Haixia Du $\mathbb{D},{ }^{1}$ Huifen Zhou, ${ }^{1}$ Jiehong Yang $\left(\mathbb{D},{ }^{2}\right.$ Jiaqi Zhu, ${ }^{2}$ Xin Tong, ${ }^{1}$ \\ Yuting Yang, ${ }^{1}$ Jiayang Wan, ${ }^{3}$ Yichen Fan, ${ }^{1}$ Yiyu Lu, ${ }^{4}$ Yu He $\mathbb{D}^{5},{ }^{5}$ and Haitong Wan ${ }^{1,2}$ \\ ${ }^{1}$ School of Life Science, Zhejiang Chinese Medical University, Hangzhou 310053, China \\ ${ }^{2}$ College of Basic Medicine, Zhejiang Chinese Medical University, Hangzhou 310053, China \\ ${ }^{3}$ Department of Obstetrics and Gynecology, Peking University First Hospital, Beijing 100034, China \\ ${ }^{4}$ Institute of Microbiology, Zhejiang Center for Disease Control and Prevention, Hangzhou 310009, China \\ ${ }^{5}$ College of Pharmaceutical Science, Zhejiang Chinese Medical University, Hangzhou 310053, China
}

Correspondence should be addressed to Yu He; heyu0923@sina.com and Haitong Wan; whtong@126.com

Received 31 August 2021; Revised 16 December 2021; Accepted 21 January 2022; Published 15 February 2022

Academic Editor: Ali Imran

Copyright (c) 2022 Tianhang Chen et al. This is an open access article distributed under the Creative Commons Attribution License, which permits unrestricted use, distribution, and reproduction in any medium, provided the original work is properly cited.

\begin{abstract}
Background. Traditional Chinese medicine Yinhuapinggan granule (YHPG) has been used for treating upper respiratory tract infection like influenza, cough, and viral pneumonia. However, its active ingredients that really exert the main efficacy have not been well elucidated. This study is aimed at screening its antiviral components and investigating the potential therapeutic mechanisms of YHPG against the influenza A/PR8/34 (H1N1) virus in Madin Darby canine kidney (MDCK). Methods. MDCK cells were infected with the influenza virus and then treated with ribavirin, YHPG, and main active ingredients in YHPG. Based on the maximum nontoxic concentration $\left(\mathrm{TC}_{0}\right)$, half-maximal toxic concentration $\left(\mathrm{TC}_{50}\right)$, half-maximal inhibitory concentration $\left(\mathrm{IC}_{50}\right.$ ), and therapeutic index (TI), interferon- $\beta$ (IFN- $\beta$ ) and interleukin-6 (IL-6) levels were measured using enzyme-linked immunosorbent assay (ELISA), and the gene expression of TLR7, MyD88, tumor necrosis factor receptorassociated factor 6 (TRAF6), c-Jun amino terminal kinase (JNK), p38 mitogen-activated protein kinase (p38 MAPK), and p65 nuclear transcription factor-kappa B (p65 NF- $\kappa$ B) was quantified using reverse transcription-polymerase chain reaction (RTPCR). Results. The results indicated that the components of YHPG, such as ephedrine hydrochloride, pseudoephedrine hydrochloride, chlorogenic acid, and emodin, had significant antiviral effects. High and medium doses of YHPG effectively reduced the cytopathic effect (CPE) and significantly decreased IFN- $\beta$ and IL- 6 levels in the supernatant. Simultaneously, the transcript levels of TLR7, MyD88, TRAF6, JNK, p38 MAPK, and p65 NF- $\kappa$ B decreased in infected MDCK cells. Moreover, a certain dose-dependent relationship among different groups of YHPG was observed. Conclusions. These results indicated that YHPG and the components of YHPG had a significant inhibitory function on the proliferation of the H1N1 virus. The mechanism might be associated with suppressing the activation of the TLR7/MyD88 signaling pathway, a decrease in the mRNA expression of key target genes, and inhibition of IFN- $\beta$ and IL-6 secretion.
\end{abstract}

\section{Introduction}

Influenza, which has a high incidence, extensive prevalence, and rapid dissemination, is an acute respiratory tract infection caused by the influenza virus of the family Orthomyxoviridae. The virus can be divided into the $A, B$, and $C$ types based on the nucleoprotein's antigenic characteristics. The influenza A virus tends to undergo antigenic drift, causing worldwide pandemics and seriously threatening human health. Current drug treatment for viruses mainly includes M2 ion channel and neuraminidase inhibitors such as amantadine and oseltamivir $[1,2]$. Despite their availability, these 
TABLE 1: Component herbs of YHPG.

\begin{tabular}{lcccc}
\hline Pharmaceutical name & Botanical plant name & Family & Weight (g) & Used part \\
\hline Flos Lonicerae Japonicae & Lonicera japonica Thunb. & Caprifoliaceae & 10 & Flower bud \\
Herba Ephedrae & Ephedra sinica Stapf. & Ephedraceae & 5 & Aerial part \\
Puerariae Lobatae Radix & Pueraria lobata (Willd.) Ohwi & Lamiaceae & 10 & Radix \\
Polygoni Cuspidati Rhizoma & Polygonum cuspidatum Sieb. et Zucc. & Polygonaceae & 10 & Root and rhizome \\
Armeniacae Semen Amarum & Prunus armeniaca L. var. ansu. Maxim. & Rosaceae & 5 & Fruit \\
Glycyrrhizae Radix & Glycyrrhiza uralensis Fischer & Leguminosae & 2.5 & Root and stolon \\
\hline
\end{tabular}

drugs often fail quickly due to surface antigen variation. Compared with synthetic chemical drugs, traditional Chinese medicines (TCM) against the influenza virus have the advantages of multiple targets and insignificant adverse side effects [3]. Therefore, the development and use of natural medicine and related mechanisms are necessary.

Yinhuapinggan granule (YHPG), formerly named Jin Pinggan, is based upon the classical Ephedra decoction formula and was improved by the clinical experience of Professor Wan Haitong. It is mainly composed of Flos Lonicerae Japonicae, Herba Ephedrae, Puerariae Lobatae Radix, Polygoni Cuspidati Rhizoma, Armeniacae Semen Amarum, and Glycyrrhizae Radix, with a ratio of $4: 4: 4: 2: 2: 1$ (Table 1). The high-performance liquid chromatography (HPLC) analysis of YHPG has been performed using an established method in our lab (Supplementary Figure 1) [4]. Clinical trials show that YHPG had good clinical efficacy and safety $[5,6]$. Previous studies have shown that YHPG significantly inhibited influenza virus replication in chicken embryos in vitro [7]. In vivo, YHPG was reported to relieve lung tissue injury in mice infected with the influenza A virus [8] and to possess antitussive [9], anti-inflammatory, and analgesic [10] properties. YHPG also reduced and regulated immune functions in mice, which might be associated with the regulation of Toll-like receptor (TLR) signaling pathways [4]. Thus, to elucidate the mechanism of YHPG-induced anti-influenza viral activity, this study observed the in vitro antiviral effect of YHPG in MDCK cells by examining the levels of interferon- $\beta$ (INF- $\beta$ ) and interleukin-6 (IL-6), as well as the expression levels of target genes of TLR7, MyD88, TRAF6, JNK, p38 MAPK, and p65 NF- $\kappa \mathrm{B}$ in MDCK cells infected with influenza virus. Simultaneously, we should understand the anti-influenza virus components in YHPG. This study may provide an experimental basis for further systematic research on YHPG that may promote its clinical use.

\section{Materials and Methods}

2.1. Drugs and Reagents. Flos Lonicerae Japonicae, Herba Ephedrae, Puerariae Lobatae Radix, Polygoni Cuspidati Rhizoma, Armeniacae Semen Amarum, and Glycyrrhizae Radix were purchased from Hangzhou Huadong Chinese Herbal Medicine Co., Ltd. and were identified by Prof. Shengwu Huang, College of Pharmaceutical Science, Zhejiang Chinese Medical University, where voucher specimens were deposited (Table 1). The crude slices of these drugs were in conformity with the quality standards of Chinese Pharmacopoeia (2020 edition). Ribavirin granules were obtained from Sichuan Baili Pharmaceutical Co., Ltd. Glycyrrhizic acid, puerarin, chlorogenic acid, luteoloside, polydatin, amygdalin, emodin, glycyrrhetinic acid, and linalool were purchased from Nanjing Shizhou Biotechnology Co., Ltd. (Nanjing, China). Ephedrine hydrochloride and pseudoephedrine hydrochloride were obtained from the National Institute for Food and Drug Control of China (Beijing, China). All standard substances had more than 98\% purity. Modern pharmacological studies have shown that eleven components are the main active components and are present in YHPG with a relatively high content (their chemical structures are shown in Figure 1) [4]. Minimum essential medium (MEM) culture medium, phosphate-buffered saline (PBS), penicillin and streptomycin stock solutions, fetal bovine serum (FBS), and 0.25\%-EDTA trypsin were all purchased from Gibco (California, USA). The reverse transcription reagent kit and SYBR Premix Ex $\mathrm{Taq}^{\mathrm{TM}}$ II reagent kit were obtained from TaKaRa Bio Inc. (Kusatsu, Japan). The RNA extraction reagent kit was purchased from Qiagen (Hilden, Germany). The interferon- $\beta$ (IFN- $\beta$ ) and interleukin-6 (IL6) enzyme-linked immunosorbent assay (ELISA) reagent kits were obtained from Shanghai FanKe Biological Technology Co., Ltd. (Shanghai, China).

2.2. Virus Strain and Cell Lines. Influenza A/PR8/34 (H1N1) virus was provided by the Zhejiang Provincial Center for Disease Control and Prevention. After amplification in 9day-old chicken embryos, the virus was stored at $-80^{\circ} \mathrm{C}$ for future use. The viral titer was $1: 1,024$, as determined using the hemagglutination test. MDCK cells were cultivated in MEM containing 10\% heat-inactivated FBS, $1 \% 2 \mathrm{mM} \mathrm{Lg}$, and $1 \%$ PS in a humidified atmosphere containing $5 \% \mathrm{CO}_{2}$ at $37^{\circ} \mathrm{C}$.

2.3. Measurement of Viral Infectivity Titers. To obtain nine concentrations of viral solutions $\left(10^{-1}-10^{-9}\right)$, influenza virus $\mathrm{A} / \mathrm{PR} 8 / 34$ (H1N1) was serially diluted 10-fold in viral growth medium. A $100 \mu \mathrm{L}$ aliquot of these viral solutions was added to a well of a 96-well plate containing a monolayer of confluent MDCK cells, with six replicate wells for each concentration. Meanwhile, a control group with a cell maintenance solution was included. The cells were cultured in an incubator at $37^{\circ} \mathrm{C}$ and $5 \% \mathrm{CO}_{2}$ and observed every day under an inverted microscope to evaluate the cytopathic 


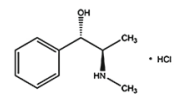

Ephedrine hydrochloride

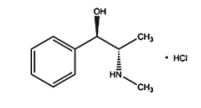

Pseudoephedrine hydrochloride

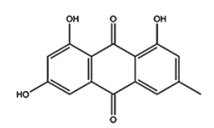

Emodin

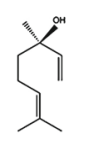

Linalool

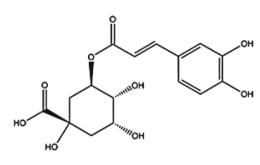

Chlorogenic acid

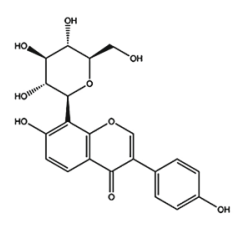

Puerarin
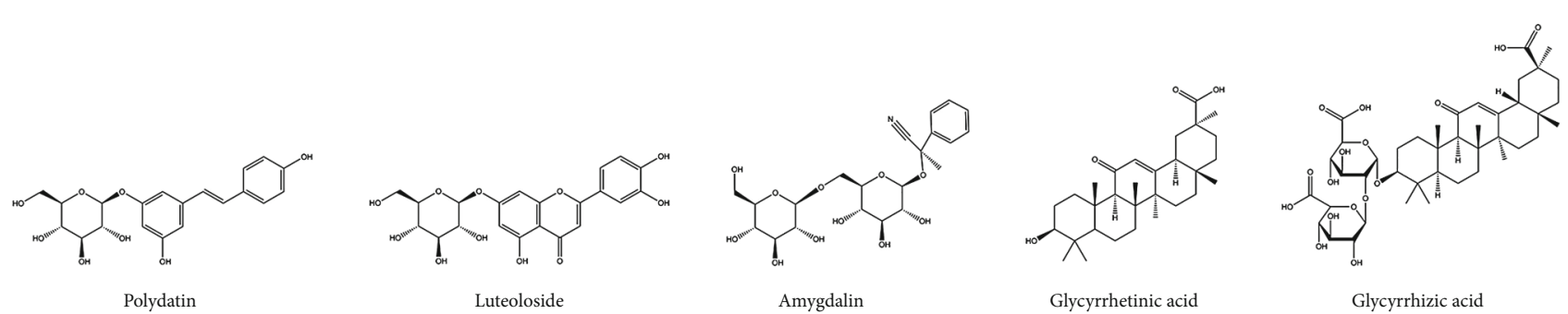

FIGURE 1: The chemical structures of eleven major components in YHPG.

effect (CPE). The 50\% tissue culture infective dose $\left(\mathrm{TCID}_{50}\right)$ was calculated using the Reed-Muench method.

2.4. Measurement of Drug Cytotoxicity. YHPG and its components (ephedrine hydrochloride, pseudoephedrine hydrochloride, glycyrrhizic acid, puerarin, chlorogenic acid, luteoloside, polydatin, amygdalin, emodin, glycyrrhetinic acid, and linalool) and ribavirin granules (positive drug) were serially diluted 2 -fold in the cell maintenance solution. MDCK cells at the logarithmic growth phase were inoculated into 96-well plates and cultured at $37^{\circ} \mathrm{C}$ and $5 \% \mathrm{CO}_{2}$. One hundred $\mu \mathrm{L}$ aliquot of YHPG at 10 concentrations, from 10 to $0.020 \mathrm{mg} \cdot \mathrm{mL}^{-1}$, ephedrine hydrochloride from 125 to $0.98 \mu \mathrm{g} \cdot \mathrm{mL}^{-1}$, pseudoephedrine hydrochloride from 125 to $0.98 \mu \mathrm{g} \cdot \mathrm{mL}^{-1}$, glycyrrhizic acid from 1,000 to $7.81 \mu \mathrm{g} \cdot \mathrm{mL}^{-1}$, puerarin from 1,000 to $7.81 \mu \mathrm{g} \cdot \mathrm{mL}^{-1}$, chlorogenic acid from 1,000 to $7.81 \mu \mathrm{g} \cdot \mathrm{mL}^{-1}$, luteoloside from 1,000 to $7.81 \mu \mathrm{g} \cdot \mathrm{mL}^{-1}$, polydatin from 2,000 to $15.63 \mu \mathrm{g} \cdot \mathrm{mL}^{-1}$, amygdalin from 250 to $1.96 \mu \mathrm{g} \cdot \mathrm{mL}^{-1}$, emodin from 125 to $0.98 \mu \mathrm{g} \cdot \mathrm{mL}^{-1}$, glycyrrhetinic acid from 1,000 to $7.81 \mu \mathrm{g} \cdot \mathrm{mL}^{-1}$, and linalool from 2,000 to $15.63 \mu \mathrm{g} \cdot \mathrm{mL}^{-1}$ at eight concentrations, and ribavirin granule at 10 concentrations, from 25 to $0.050 \mathrm{mg} \cdot \mathrm{mL}^{-1}$, were added to each well. Each concentration was repeated six times, and a control group with cell maintenance solution was included. After the cells were routinely incubated for $48 \mathrm{~h}, 20 \mu \mathrm{L}$ of $5 \mathrm{mg} \cdot \mathrm{mL}^{-1} \quad 3$-(4,5-dimethylthiazol-2-yl)-2,5-diphenyltetrazolium bromide (MTT) solution was added, and the cells were cultured for another $4 \mathrm{~h}$. The supernatant was discarded, and $150 \mu \mathrm{L} /$ well dimethyl sulfoxide (DMSO) was added; the cells were then shaken at low speed for $15 \mathrm{~min}$ on a shaker until the crystallized deposits were completely dissolved. The absorbance value of each well at $490 \mathrm{~nm}$ was measured using a microplate reader. Cell survival and inhibition rates were calculated according to the following formulae:

$$
\begin{aligned}
\text { Cell survival rate }(\%)= & (\text { average absorbance value of } \\
& \text { the drug group/average } \\
& \text { absorbance value of the } \\
& \text { control group }) \times 100 \%,
\end{aligned}
$$

$$
\text { Cell inhibition rate }(\%)=100 \% \text { - cell survival rate. }
$$

In addition, the half-maximal toxic concentration $\left(\mathrm{TC}_{50}\right)$ and the maximum nontoxic concentration $\left(\mathrm{TC}_{0}\right)$ were calculated using the Reed-Muench method.

\subsection{Antiviral Mode of Action}

2.5.1. Preventive Function. Starting from the maximum nontoxic concentration, the YHPG $\left(0.625 \mathrm{mg} \cdot \mathrm{mL}^{-1}\right.$, $0.3125 \mathrm{mg} \cdot \mathrm{mL}^{-1}$, and $\left.0.156 \mathrm{mg} \cdot \mathrm{mL}^{-1}\right)$ and ribavirin $\left(0.780 \mathrm{mg} \cdot \mathrm{mL}^{-1}, 0.390 \mathrm{mg} \cdot \mathrm{mL}^{-1}\right.$, and $\left.0.195 \mathrm{mg} \cdot \mathrm{mL}^{-1}\right)$ solutions were serially diluted 2 -fold in cell maintenance solution. After reaching confluent monolayers in 96-well plates, the supernatant was discarded, and the cells were washed twice with PBS; $100 \mu \mathrm{L}$ of the different drug concentrations was added to each well, with six replicate wells for each concentration. Control (with cell maintenance solution only) and mock groups (with the virus only) were included. After incubation at $37^{\circ} \mathrm{C}$ and $5 \% \mathrm{CO}_{2}$ for $1 \mathrm{~h}$, the drug solution was discarded, and $100 \mu \mathrm{L}$ of the diluted virus at $10 \mathrm{TCID}_{50}$ was added. After adsorption at $37^{\circ} \mathrm{C}$ and $5 \% \mathrm{CO}_{2}$ for $1 \mathrm{~h}$, the supernatant was discarded, and the MEM cell maintenance solution was added.

2.5.2. Therapeutic Effects. The diluted virus at $10 \mathrm{TCID}_{50}$ was added to a 96-well plate. After adsorption for $1 \mathrm{~h}, 100 \mu \mathrm{L}$ of different concentrations of prediluted YHPG or ribavirin solution was added to each well, with six replicate wells for each concentration. Control and mock groups were set up.

For the two experiments described above, CPE was observed every day under an inverted microscope. When $\mathrm{CPE}$ in the mock group reached $75 \%$, absorbance at $490 \mathrm{~nm}$ was assessed using the MTT method to calculate cell survival rates, the antiviral effect of the drugs, the halfmaximal inhibitory concentration $\left(\mathrm{IC}_{50}\right)$, and the therapeutic index (TI).

Antiviral effectiveness of drugs $(\%)=$ (average absorbance value of the drug group-average absorbance value of the mock group )/(average absorbance value of the control group - average absorbance value of the mock group ) $\times 100 \%$. 
TABLE 2: Sequences of gene primers and fragments of products.

\begin{tabular}{llc}
\hline Target gene & Primer sequence $\left(5^{\prime} \rightarrow 3^{\prime}\right)$ & $\begin{array}{c}\text { Product } \\
\text { length }(\mathrm{bp})\end{array}$ \\
\hline M1 & $\begin{array}{l}\text { TCATTGGGATCTTGCACTTG } \\
\text { ACTTTGGCACTCCTTCCGTA }\end{array}$ & 117 \\
& $\begin{array}{l}\text { TGCTCTGCTCTCTTCAACCAG } \\
\text { MyD88 }\end{array}$ & 199 \\
& CAATCACATGGGCCTTCGGA & \\
TRAF6 & CAAATGCTGGCATGTTGGGT & \\
& CGTGTCACCCAGAGGTTCAG & 200 \\
JNK & GTAGATCCCGTTGCACTGCT & \\
& CTCCCCTTTGTCTTGCACTC & 118 \\
p38 MAPK & CAACCCACAGCAGGGAAATC & \\
& ACAGAAACCAGGTGCTCAGG & \\
p65 NF- $\kappa$ B & CAGCCATGGACGACCTGTTTC & 113 \\
& CTGCTTGGGTTGCTCGATGA & \\
GAPDH & GTGACACCCACTCTTCCACC & 162 \\
& GTGGTCCAGGAGGCTCTTAC & \\
\hline
\end{tabular}

$$
\mathrm{TI}=\mathrm{TC}_{50} / \mathrm{IC}_{50}
$$

2.6. Screening of Active Components from YHPG against Influenza $A$ (H1N1) Virus. Starting from TC $\mathrm{T}_{0}$, YHPG and its components (ephedrine hydrochloride, pseudoephedrine hydrochloride, glycyrrhizic acid, puerarin, chlorogenic acid, luteoloside, polydatin, amygdalin, emodin, glycyrrhetinic acid, and linalool) were diluted to five concentrations of drug-containing solution under maximum nontoxic concentration, and ribavirin was diluted to $780 \mu \mathrm{g} \cdot \mathrm{mL}^{-1}$. The MDCK cells were cultured on 96-well plates until they grew into a monolayer; the cells were then inoculated with 10 TCID $_{50} \mathrm{H} 1 \mathrm{N1}$ virus, $100 \mu \mathrm{L} /$ well, adsorbed in a $5 \% \mathrm{CO}_{2}$ incubator at $37^{\circ} \mathrm{C}$ for $1 \mathrm{~h}$, and then washed with PBS three times. After adding the above concentration of drugs, the cells were kept in culture with $100 \mu \mathrm{L} /$ well and six replicate wells for each concentration. Control and mock groups were set up. After $48 \mathrm{~h}$, the CCK- 8 method was used to calculate the antiviral effectiveness of the drugs.

2.7. Analysis of Viral Load by RT-PCR. The drug concentration with high antiviral efficiency under the $\mathrm{TC}_{0}$ was selected for the experiment. The experiment was divided into 12 groups: a control group, the mock group, the control+YHPG group $\left(625 \mu \mathrm{g} \cdot \mathrm{mL}^{-1}\right)$, the ribavirin group $\left(780 \mu \mathrm{g} \cdot \mathrm{mL}^{-1}\right)$, the YHPG high-dose group $\left(625 \mu \mathrm{g} \cdot \mathrm{mL}^{-1}\right)$, the YHPG mediumdose group $\left(312.5 \mu \mathrm{g} \cdot \mathrm{mL}^{-1}\right)$, the YHPG low-dose group $\left(56.25 \mu \mathrm{g} \cdot \mathrm{mL}^{-1}\right)$, the ephedrine hydrochloride group $\left(62.5 \mu \mathrm{g} \cdot \mathrm{mL}^{-1}\right)$, the pseudoephedrine hydrochloride group $\left(62.5 \mu \mathrm{g} \cdot \mathrm{mL}^{-1}\right)$, the chlorogenic acid group $\left(31.25 \mu \mathrm{g} \cdot \mathrm{mL}^{-1}\right)$, the luteoloside group $\left(250 \mu \mathrm{g} \cdot \mathrm{mL}^{-1}\right)$, and the emodin group $\left(62.5 \mu \mathrm{g} \cdot \mathrm{mL}^{-1}\right)$. The MDCK cells were seeded on 6-well plates with $5 \times 10^{5} / \mathrm{mL}, 2.5 \mathrm{~mL} /$ well until the cells grew to $70 \% \sim 80 \%$. Except for the control group and the contro1+YHPG medium-dose group, the other groups were inoculated with $10 \mathrm{TCID}_{50}$ virus diluent and placed in an incubator at $37^{\circ} \mathrm{C}, 5 \% \mathrm{CO}_{2}$ for $1 \mathrm{~h}$. The plates were gently shaken every $15 \mathrm{~min}$. After adsorption for $1 \mathrm{~h}$, the culture medium was discarded, PBS was added to wash the cells twice, and the above concentrations of drugs were added. The control group and mock group were added with the same volume of serum-free DMEM medium and grown in a cell incubator (Thermo Scientific, Waltham, MA, USA) in an atmosphere of $5 \% \mathrm{CO}_{2}$ at $37^{\circ} \mathrm{C}$ for $24 \mathrm{~h}$, and $\mathrm{CPE}$ was observed at $24 \mathrm{~h}$. Then, the samples were stored at $-80^{\circ} \mathrm{C}$ for RT-PCR analysis. The total RNA from the cells was extracted with RNeasy Mini (QIAGEN, Germany) and finally dissolved in $40 \mu \mathrm{L}$ of RNase-free water. RT-PCR assay was performed on cDNA samples via the SYBR Premix Ex Taq $^{\text {TM }}$ II (Takara, Dalian, China). The primer sequences that were used to amplify the influenza virus M1 gene (IFV-M1) and glyceraldehyde 3-phosphate dehydrogenase (GAPDH) (Table 2) were designed and synthesized by Sangon Biotech, Co., Ltd. (Shanghai, China). The reaction conditions were $95^{\circ} \mathrm{C}$ for $2 \mathrm{~min}$, followed by $95^{\circ} \mathrm{C}$ for $15 \mathrm{~s}$ for 40 cycles of denaturation and extended at $55^{\circ} \mathrm{C}$ for $35 \mathrm{~s}$. RT-PCR analysis was performed using an automatic thermocycler (QuantStudio 12K Flex Real-Time PCR System, Applied Biosystems Co., USA). The relative expression levels of the target genes were quantified using the $2^{-\Delta \Delta \mathrm{Ct}}$ method and normalized using GAPDH as the internal control according to the following equation:

$$
\begin{aligned}
{ }^{\Delta \Delta} \mathrm{Ct}= & \left(\mathrm{Ct}_{\text {target gene }}-\mathrm{Ct}_{\text {internal control }}\right) \text { experimental group } \\
& -\left(\mathrm{Ct}_{\text {target gene }}-\mathrm{Ct}_{\text {internal control }}\right)_{\text {control group }}
\end{aligned}
$$

2.8. Detection of IFN- $\beta$ and IL-6 Secretion Levels by ELISA. After growing to a confluent monolayer in plates, $2 \mathrm{~mL} /$ well of the diluted virus at $10 \mathrm{TCID}_{50}$ was added. The cell maintenance solution was added to the control group. After viral adsorption for $1 \mathrm{~h}$, the supernatant was discarded; diluted YHPG and ribavirin solutions were added to the drug treatment groups, whereas the virus growth medium was added to the mock group. The cells were incubated at $37^{\circ} \mathrm{C}$ and $5 \% \mathrm{CO}_{2}$ for $24 \mathrm{~h}$. After the cell supernatant was collected, the IFN- $\beta$ and IL-6 secretion levels were measured using the ELISA kits according to the manufacturer's manual.

2.9. Detection of the Expression of Related Genes by RT-PCR. Diluted virus at $10 \mathrm{TCID}_{50}$ was added ( $1 \mathrm{~mL} /$ flask) to confluent MDCK cells in a T25 cell culture flask. After virus adsorption for $1 \mathrm{~h}$, the supernatant was discarded, and the cells were washed twice with PBS; different doses of YHPG (a high dose of $0.625 \mathrm{mg} \cdot \mathrm{mL}^{-1}$, a medium dose of $0.313 \mathrm{mg} \cdot \mathrm{mL}^{-1}$, and a low dose of $0.156 \mathrm{mg} \cdot \mathrm{mL}^{-1}$ ) were then added. In addition, the control, mock, and ribavirin $\left(0.780 \mathrm{mg} \cdot \mathrm{mL}^{-1}\right)$ groups were included. The cells were continuously cultured at $37^{\circ} \mathrm{C}$ and $5 \% \mathrm{CO}_{2}$ for $24 \mathrm{~h}$. Total RNA was extracted from each sample. cDNA synthesis and RT-PCR were performed. The operation methods were the same as Analysis of Viral Load by RT-PCR. All primers were synthesized by Shanghai Sangon Biotechnology Co. Ltd. The primer sequences are shown in Table 2. The threshold cycle (Ct) value of each sample was calculated using the relative 
quantitation method and glyceraldehyde 3-phosphate dehydrogenase $(\mathrm{GAPDH})$ as the internal control. The relative mRNA expression levels in all groups were calculated using the $2^{-\Delta \Delta \mathrm{Ct}}$ formula.

2.10. Statistical Analysis. SPSS19.0 statistical software was used. Experimental data were expressed as the mean \pm standard deviation $(\bar{x} \pm s)$, and comparison of measured data among groups was performed using one-way analysis of variance. Pairwise comparison among groups was performed using the least significant difference (LSD) $t$-test when variances were homogeneous; when variances were not homogeneous, the Tamhane test was used. $P<0.05$ indicated a significant difference, and $P<0.01$ indicated a highly significant difference.

\section{Results}

3.1. Measurement of Viral Infectivity Titers. According to the experimental results, the $\mathrm{TCID}_{50}$ of influenza A/PR8/34 (H1N1) virus was $10^{-3.5} / 0.1 \mathrm{~mL}$, as calculated using the Reed-Muench method.

3.2. Measurement of Drug Cytotoxicity. The morphological changes of the MDCK cells were observed by a microscope. The cells became round, shrunk, and adhesive and the intercellular space increased. Some cells were detached. The $\mathrm{TC}_{50}$ and $\mathrm{TC}_{0}$ for YHPG, YHPG's components, and ribavirin granules are shown in Table 3.

3.3. Antiviral Mode of Action. The preventive function of YHPG and ribavirin granules against the influenza virus was not obvious, with antiviral effectiveness values of $<$ 30\% (Table 4). Also, all MDCK cells exhibited CPE at all concentrations of YHPG (Figure 2).

YHPG at concentrations of 0.313 and $0.625 \mathrm{mg} \cdot \mathrm{mL}^{-1}$ had obvious therapeutic effects on the influenza virus (Figure 3 ), with antiviral effectiveness $>90 \%$, and CPE gradually increased with the drug concentration. At concentrations of $0.156-0.625 \mathrm{mg} \cdot \mathrm{mL}^{-1}$ YHPG, the antiviral effectiveness was $>50 \%$, the same antiviral effectiveness achieved with $0.390-0.780 \mathrm{mg} \cdot \mathrm{mL}^{-1}$ ribavirin. The antiviral effectiveness of ribavirin was $>90 \%$ at $0.780 \mathrm{mg} \cdot \mathrm{mL}^{-1}$. The specific $\mathrm{IC}_{50}$ and TI values are shown in Table 5.

3.4. Effect of YHPG and the Main Active Components on Influenza A/H1N1 Virus. YHPG and its active components (ephedrine hydrochloride, pseudoephedrine hydrochloride, glycyrrhizic acid, puerarin, chlorogenic acid, luteoloside, polydatin, amygdalin, emodin, glycyrrhetinic acid, and linalool) in different concentrations acted on MDCK cells infected with influenza A/H1N1 virus. The corresponding antiviral effective rates are shown in Table 6 . We found that glycyrrhizic acid, puerarin, polydatin, amygdalin, glycyrrhetinic acid, and linalool had no obvious antiviral effect, and their antiviral efficiency was less than $60 \%$. The antiviral effects of luteoloside and emodin groups were obvious, and the antiviral efficiency of the maximum nontoxic concentration was more than 60\%. The antiviral effect of YHPG and ephedrine hydrochloride, pseudoephedrine hydrochloride,
TABLE 3: $\mathrm{TC}_{50}$ and $\mathrm{TC}_{0}$ of YHPG, active components, and ribavirin granules $(n=6)$.

\begin{tabular}{lcc}
\hline Group & $\mathrm{TC}_{50}\left(\mathrm{mg} \cdot \mathrm{mL}^{-1}\right)$ & $\mathrm{TC}_{0}\left(\mathrm{mg} \cdot \mathrm{mL}^{-1}\right)$ \\
\hline YHPG & 0.970 & 0.625 \\
Ribavirin granule & 1.316 & 0.780 \\
Ephedrine hydrochloride & 8.260 & 0.0625 \\
Pseudoephedrine & 6.012 & 0.0625 \\
hydrochloride & 6.375 & 0.0625 \\
Glycyrrhizic acid & 4.030 & 0.03125 \\
Chlorogenic acid & 3.076 & 0.125 \\
Puerarin & 4.766 & 0.250 \\
Luteoloside & 6.155 & 0.125 \\
Polydatin & 7.636 & 0.0625 \\
Amygdalin & 2.901 & 0.0625 \\
Emodin & 6.863 & 0.0625 \\
Glycyrrhetinic acid & 15.433 & 0.0625 \\
Linalool & &
\end{tabular}

TABLE 4: The antiviral efficacy of different concentrations of YHPG and ribavirin on influenza $\mathrm{A} / \mathrm{H} 1 \mathrm{~N} 1$ virus in preventive functions $(n=6)$.

\begin{tabular}{lcc}
\hline Group & $\begin{array}{c}\text { Drug concentration } \\
\left(\mathrm{mg} \cdot \mathrm{mL}^{-1}\right)\end{array}$ & $\begin{array}{c}\text { Antiviral efficiency } \\
(\%)\end{array}$ \\
\hline $\begin{array}{l}\text { Ribavirin } \\
\text { granule }\end{array}$ & 0.780 & $29.15 \pm 2.04$ \\
& 0.625 & $27.96 \pm 2.55$ \\
YHPG & 0.313 & $15.54 \pm 2.56$ \\
& 0.156 & $7.36 \pm 2.82$ \\
\hline
\end{tabular}

and chlorogenic acid groups was evident. Furthermore, there was a positive correlation between antiviral efficacy and drug concentration.

3.5. Effect of YHPG and the Main Active Components on CPE and Viral Load. When MDCK cells were infected with influenza A virus, the morphology of MDCK cells changed, and the cells shrunk and became detached, most of them adhering to each other in suspension at the surface of the medium; YHPG and its active components ephedrine hydrochloride, pseudoephedrine hydrochloride, chlorogenic acid, luteoloside, emodin, and ribavirin could significantly reduce the CPE (Figure 4). No viral RNA was detected in uninfected control cells (Figure 5). After H1N1 infection, the mock group's viral load was significantly higher than that of the control group. Compared with the mock group, the viral load in each dose group of YHPG, ephedrine hydrochloride, pseudoephedrine hydrochloride, chlorogenic acid, luteoloside, emodin, and ribavirin was significantly decreased after $24 \mathrm{~h}(P<0.01)$. Moreover, after $24 \mathrm{~h}$ treatment, the decrease in the viral load in the YHPG $625 \mu \mathrm{g} \cdot \mathrm{mL}^{-1}$, ephedrine hydrochloride, pseudoephedrine hydrochloride, chlorogenic acid, emodin, and ribavirin was more obvious. 


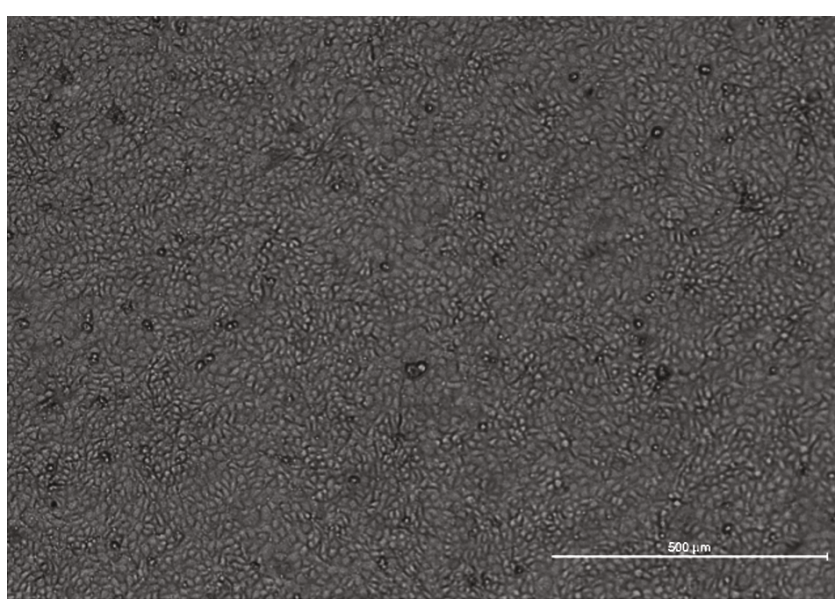

(a)

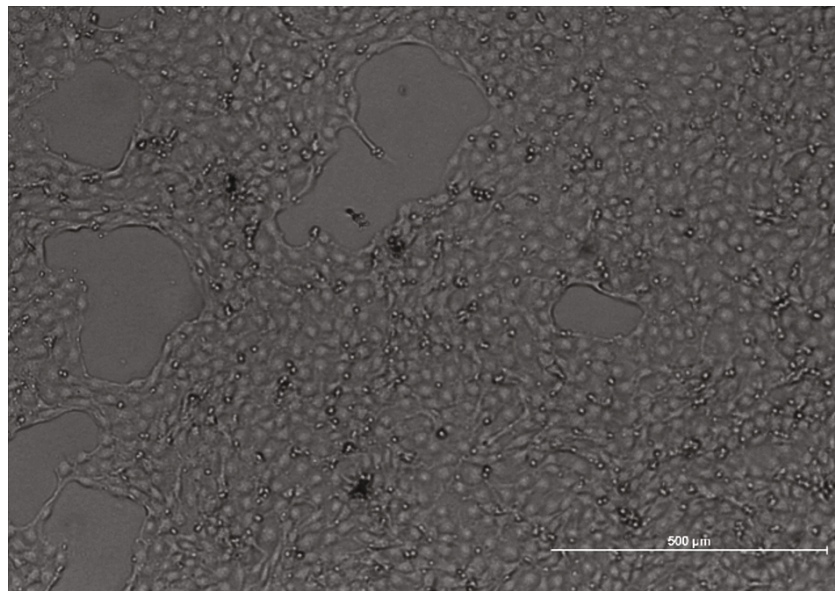

(c)

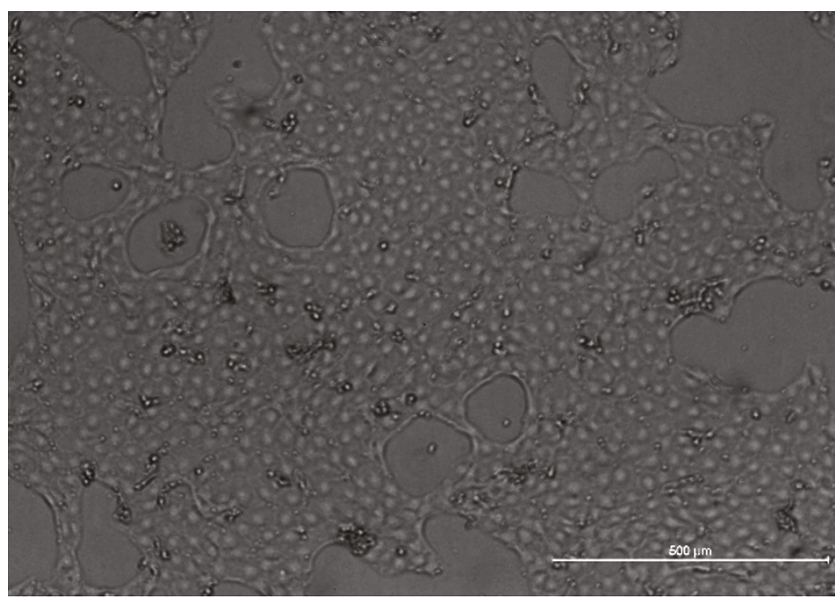

(e)

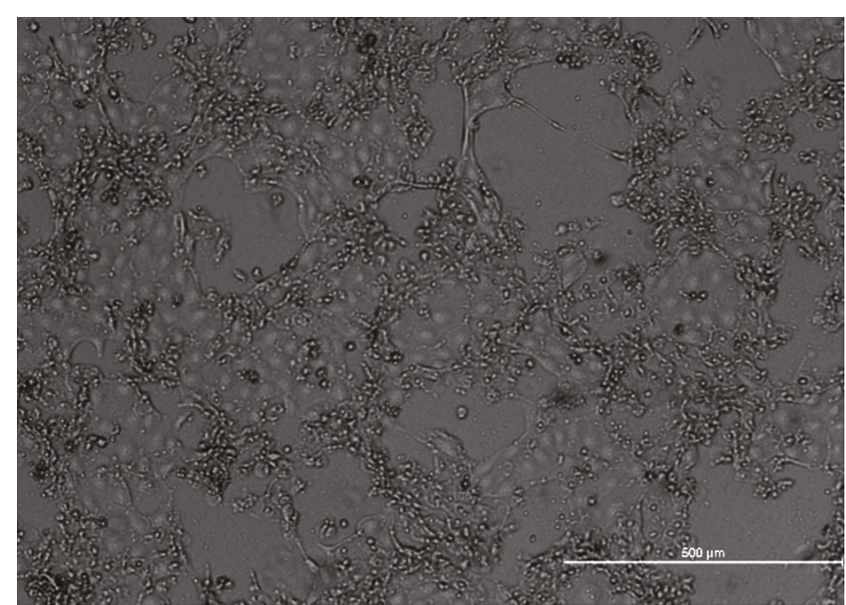

(b)

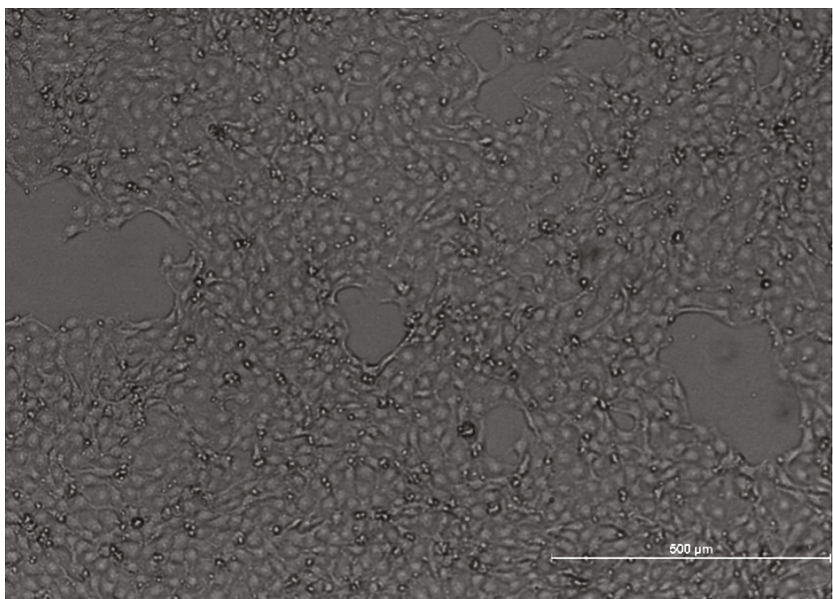

(d)

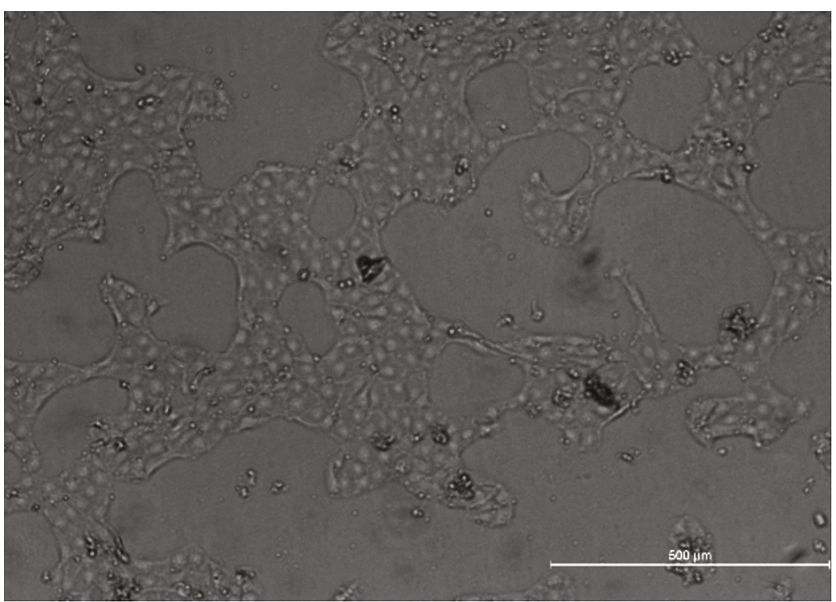

$(\mathrm{f})$

FIGURE 2: The preventive functions of YHPG and ribavirin granules against influenza virus: (a) control group; (b) mock groups; (c) ribavirin group $\left(0.780 \mathrm{mg} \cdot \mathrm{mL}^{-1}\right)$; (d) high-dose YHPG group $\left(0.625 \mathrm{mg} \cdot \mathrm{mL}^{-1}\right)$; (e) medium-dose YHPG group (0.313 mg. $\left.\mathrm{mL}^{-1}\right)$; (f) low-dose YHPG group $\left(0.156 \mathrm{mg} \cdot \mathrm{mL}^{-1}\right)$.

3.6. Detection of IFN- $\beta$ and IL-6 Secretion Levels Using ELISA. The fitted regression equations of the control samples of IFN- $\beta$ and IL-6 were $Y=64.119 X-3.8592\left(R^{2}=\right.$ $0.9969)$ and $Y=836.79 X-23.329\left(R^{2}=0.9974\right)$, respec- tively. Based on these equations, the levels of IFN- $\beta$ and IL-6 in samples were measured (Figure 6). Compared with the control group, the secretion levels of IFN- $\beta$ and IL- 6 in the mock group significantly increased $(P<0.01)$. 


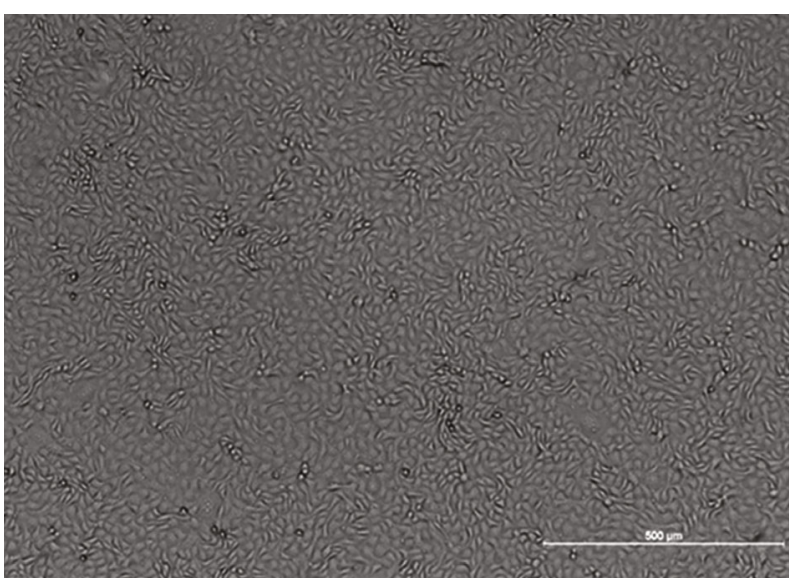

(a)

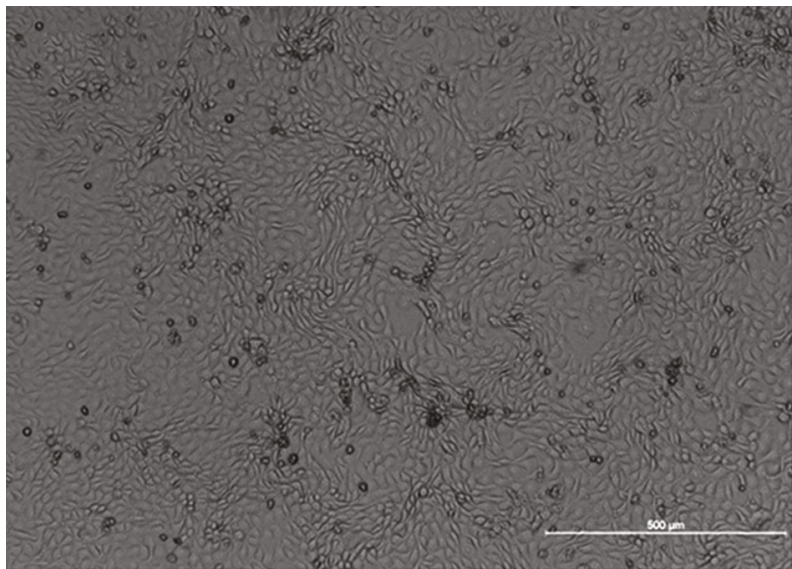

(c)

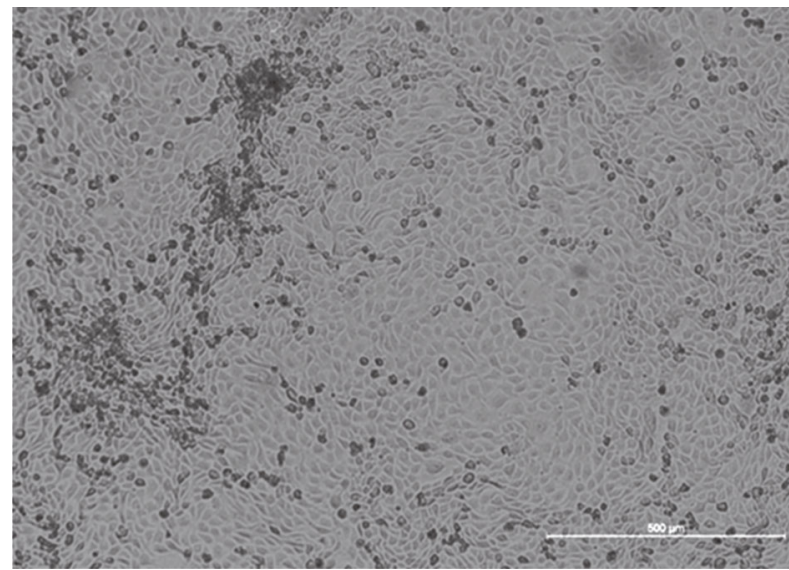

(e)

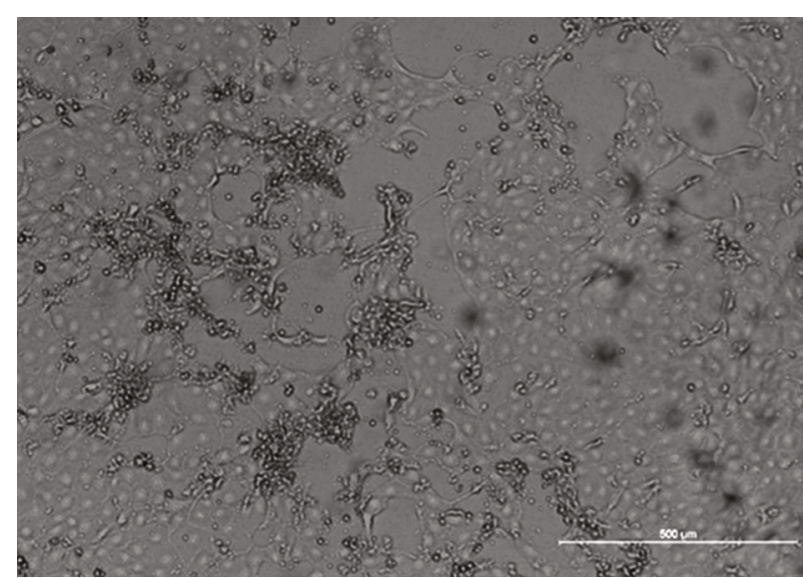

(b)

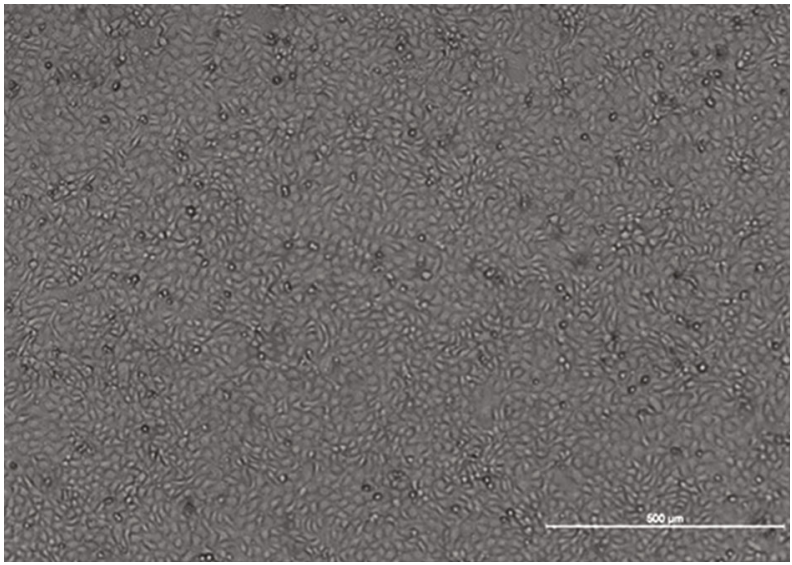

(d)

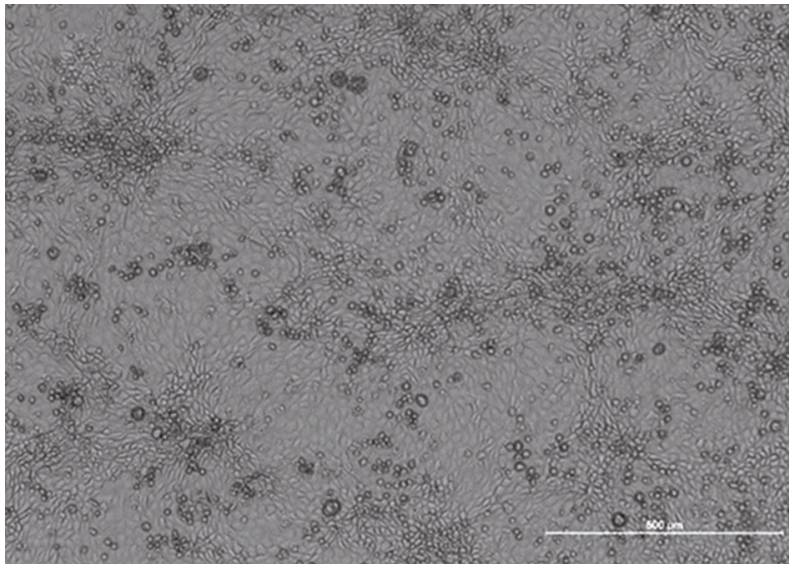

(f)

FIGURE 3: The therapeutic effect of YHPG and ribavirin granules on influenza virus: (a) control group; (b) mock groups; (c) ribavirin group $\left(0.780 \mathrm{mg} \cdot \mathrm{mL}^{-1}\right)$; (d) high-dose YHPG group $\left(0.625 \mathrm{mg} \cdot \mathrm{mL}^{-1}\right)$; (e) medium-dose YHPG group (0.313 mg.mL $\left.\mathrm{mL}^{-1}\right)$; (f) low-dose YHPG group $\left(0.156 \mathrm{mg} \cdot \mathrm{mL}^{-1}\right)$.

Compared with the mock group, the YHPG groups of high and medium doses all exhibited significantly decreased IFN- $\beta$ and IL- 6 levels $(P<0.01)$, whereas no significant difference was observed for the low-dose group. Also, there was a certain dose-dependent relationship among different YHPG groups.
3.7. Detection of the Expression of Related Genes in MDCK Cells Infected with the Influenza Virus Using RT-PCR. The levels of TLR7, MyD88, TRAF6, JNK, p38 MAPK, and p65 $\mathrm{NF}-\kappa \mathrm{B}$ gene expression in the mock group were significantly upregulated compared with those in the control group $(P<0.01)$, suggesting that the influenza virus activated the 
TABLE 5: Inhibitory functions of YHPG and ribavirin granules on influenza A/H1N1 virus $(n=6)$.

\begin{tabular}{lcccc}
\hline \multirow{2}{*}{ Group } & YHPG & & \multicolumn{2}{c}{ Ribavirin granule } \\
& Therapeutic group & Preventive group & Therapeutic group & Preventive group \\
\hline $\mathrm{IC}_{50}\left(\mathrm{mg} \cdot \mathrm{mL}^{-1}\right)$ & 0.121 & 1.030 & 0.209 & 1.473 \\
$\mathrm{TI}$ & 8.020 & 0.940 & 6.300 & 0.890 \\
\hline
\end{tabular}

TABLE 6: Comparison of antiviral efficacy of different concentrations of YHPG and its active components on influenza A/H1N1 virus.

\begin{tabular}{|c|c|c|c|c|c|}
\hline Group & $\begin{array}{c}\text { Drug concentration } \\
\qquad\left(\mu \mathrm{g} \cdot \mathrm{mL}^{-1}\right)\end{array}$ & $\begin{array}{c}\text { Antiviral } \\
\text { efficiency (\%) }\end{array}$ & Group & $\begin{array}{c}\text { Drug concentration } \\
\left(\mu \mathrm{g} \cdot \mathrm{mL}^{-1}\right)\end{array}$ & $\begin{array}{c}\text { Antiviral } \\
\text { efficiency (\%) }\end{array}$ \\
\hline \multirow{5}{*}{ YHPG } & 39.06 & $46.66 \pm 3.69$ & \multirow{5}{*}{$\begin{array}{c}\text { Ephedrine } \\
\text { hydrochloride }\end{array}$} & 3.91 & $55.32 \pm 2.59$ \\
\hline & 78.13 & $58.17 \pm 2.72$ & & 7.81 & $65.34 \pm 2.47$ \\
\hline & 156.25 & $67.43 \pm 3.87$ & & 15.63 & $69.30 \pm 2.63$ \\
\hline & 312.50 & $74.82 \pm 1.85$ & & 31.25 & $86.90 \pm 2.94$ \\
\hline & 625.00 & $86.41 \pm 2.91$ & & 62.50 & $90.82 \pm 3.92$ \\
\hline \multirow{5}{*}{$\begin{array}{l}\text { Pseudoephedrine } \\
\text { hydrochloride }\end{array}$} & 3.91 & $62.84 \pm 1.98$ & \multirow{5}{*}{ Chlorogenic acid } & 1.95 & $65.89 \pm 2.14$ \\
\hline & 7.81 & $66.04 \pm 3.15$ & & 3.91 & $70.29 \pm 2.12$ \\
\hline & 15.63 & $81.13 \pm 3.78$ & & 7.81 & $77.51 \pm 3.46$ \\
\hline & 31.25 & $87.06 \pm 2.47$ & & 15.63 & $80.22 \pm 3.92$ \\
\hline & 62.50 & $90.80 \pm 3.84$ & & 31.25 & $84.80 \pm 1.88$ \\
\hline \multirow{5}{*}{ Emodin } & 3.91 & $14.48 \pm 1.84$ & \multirow{5}{*}{ Luteoloside } & 15.63 & $14.52 \pm 3.99$ \\
\hline & 7.81 & $35.55 \pm 2.47$ & & 31.25 & $27.46 \pm 2.76$ \\
\hline & 15.63 & $50.80 \pm 3.48$ & & 62.50 & $29.97 \pm 3.46$ \\
\hline & 31.25 & $75.57 \pm 2.29$ & & 125.00 & $47.29 \pm 2.33$ \\
\hline & 62.50 & $87.09 \pm 2.08$ & & 250.00 & $69.84 \pm 3.26$ \\
\hline \multirow{5}{*}{ Puerarin } & 7.81 & $35.48 \pm 2.78$ & \multirow{5}{*}{ Polydatin } & 7.81 & $8.68 \pm 2.87$ \\
\hline & 15.63 & $41.75 \pm 3.22$ & & 15.63 & $12.96 \pm 2.89$ \\
\hline & 31.25 & $48.93 \pm 2.99$ & & 31.25 & $16.48 \pm 1.95$ \\
\hline & 62.50 & $51.37 \pm 2.88$ & & 62.50 & $28.90 \pm 3.22$ \\
\hline & 125.00 & $59.72 \pm 3.38$ & & 125.00 & $47.27 \pm 2.38$ \\
\hline \multirow{5}{*}{ Glycyrrhizic acid } & 3.91 & $6.01 \pm 2.76$ & \multirow{5}{*}{ Amygdalin } & 3.91 & $9.59 \pm 1.99$ \\
\hline & 7.81 & $7.54 \pm 1.83$ & & 7.81 & $11.43 \pm 2.74$ \\
\hline & 15.63 & $13.78 \pm 2.81$ & & 15.63 & $19.46 \pm 2.65$ \\
\hline & 31.25 & $24.25 \pm 3.80$ & & 31.25 & $26.34 \pm 3.47$ \\
\hline & 62.50 & $38.03 \pm 3.77$ & & 62.50 & $29.29 \pm 3.15$ \\
\hline \multirow{5}{*}{ Glycyrrhetinic acid } & 3.91 & $8.81 \pm 3.63$ & \multirow{5}{*}{ Linalool } & 3.91 & $3.42 \pm 2.86$ \\
\hline & 7.81 & $10.85 \pm 2.54$ & & 7.81 & $5.67 \pm 3.05$ \\
\hline & 15.63 & $13.49 \pm 2.97$ & & 15.63 & $9.46 \pm 2.59$ \\
\hline & 31.25 & $16.21 \pm 1.31$ & & 31.25 & $15.38 \pm 3.39$ \\
\hline & 62.50 & $27.86 \pm 1.10$ & & 62.50 & $23.85 \pm 2.97$ \\
\hline Ribavirin granule & 780.00 & $92.57 \pm 3.86$ & & & \\
\hline
\end{tabular}

TLR7 pathway (Figure 7). Compared with the mock group, the expression levels of these target genes in MDCK cells infected with influenza virus were significantly reduced in the high- and medium-dose YHPG groups $(P<0.01, P<$ $0.05)$, whereas no significant difference was found for the low-dose group $(P>0.05)$.

\section{Discussion}

The influenza virus is a respiratory pathogen that affects humans and causes severe morbidity and mortality. In this experiment, the effects of YHPG on MDCK cells infected by the H1N1 virus were investigated. YHPG can disperse 


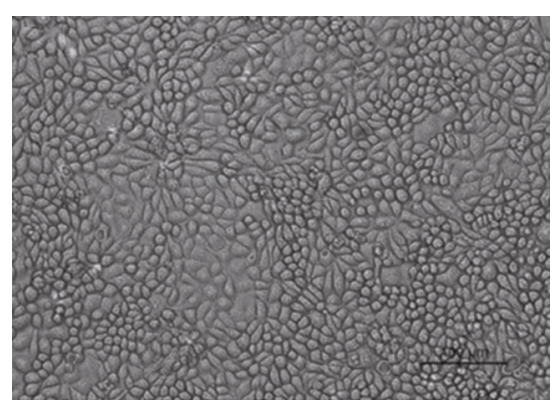

(a)

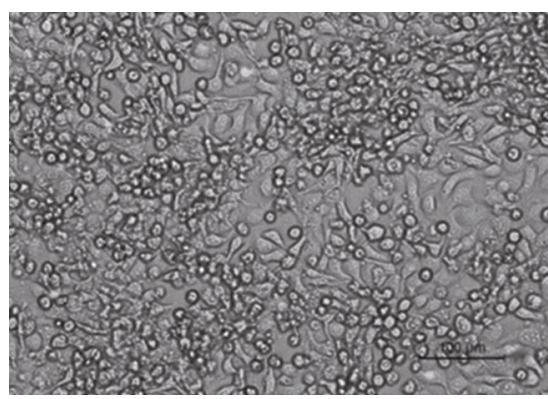

(c)

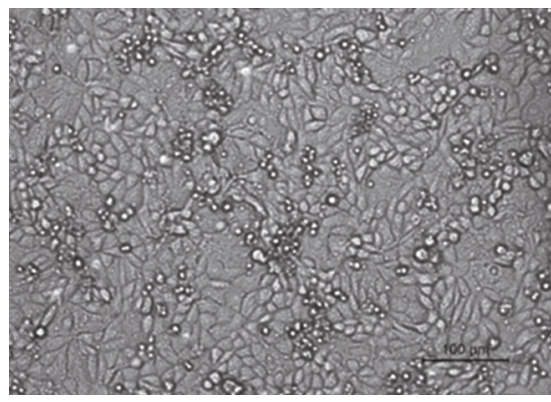

(e)

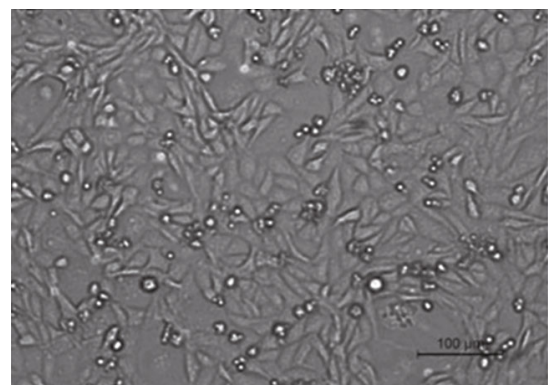

(g)

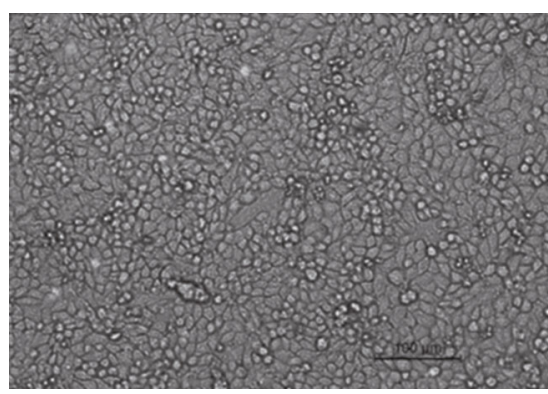

(i)

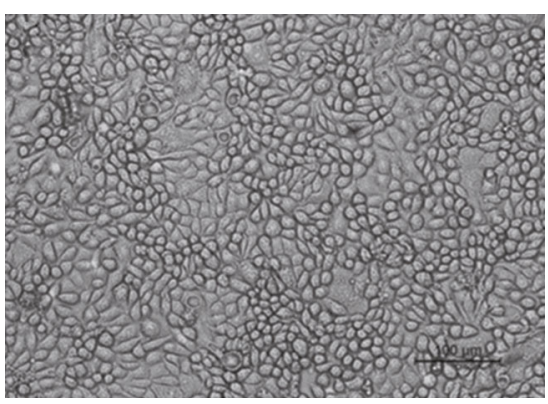

(b)

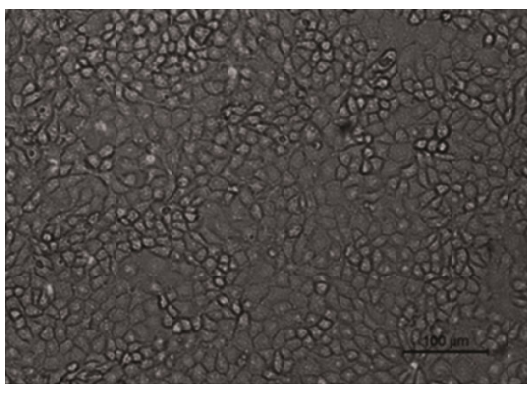

(d)

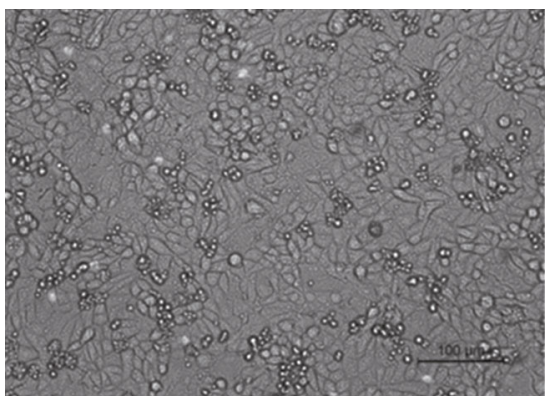

(f)

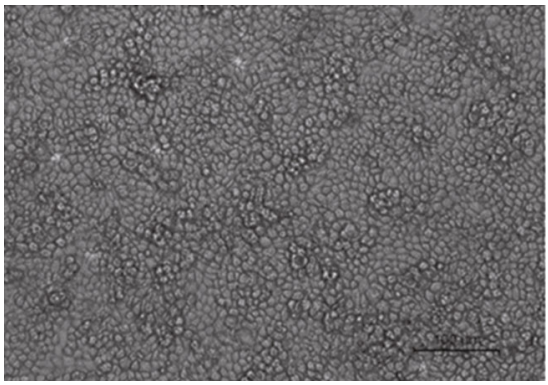

(h)

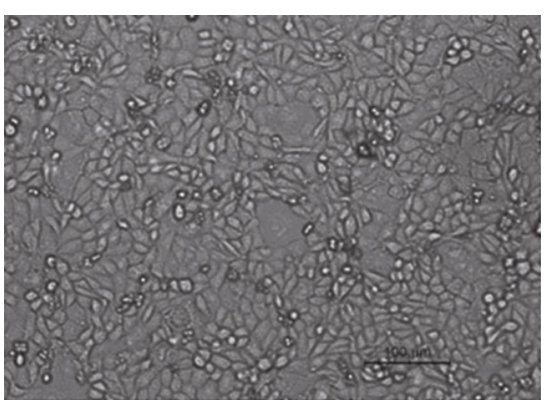

(j)

Figure 4: Continued. 


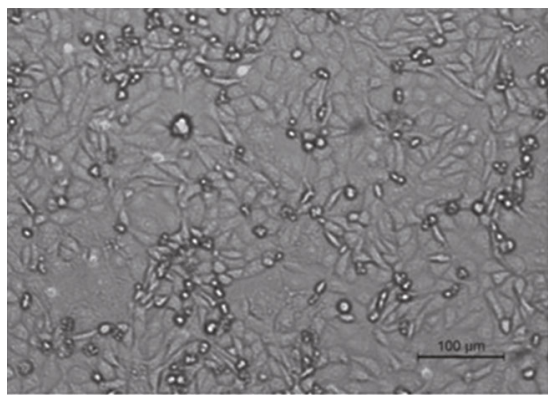

$(\mathrm{k})$

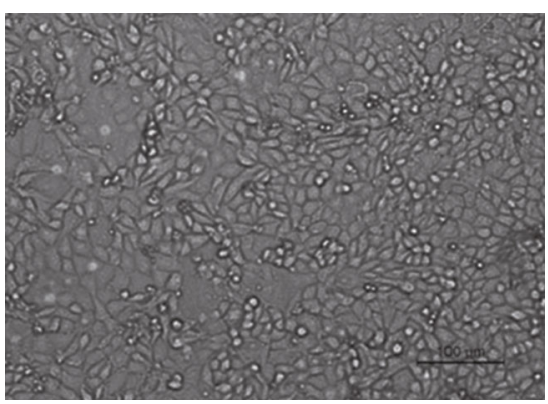

(l)

FIgURE 4: Effects of YHPG and the main active components on CPE of MDCK cells infected by influenza A/H1N1 virus ( $\times 10)$ after 24 h of treatment: (a) control group; (b) control+YHPG group $\left(625 \mu \mathrm{g} \cdot \mathrm{mL}^{-1}\right)$; (c) mock group; (d) ribavirin group $\left(780 \mu \mathrm{g} \cdot \mathrm{mL}^{-1}\right)$; (e) high-dose YHPG group $\left(625 \mu \mathrm{g} \cdot \mathrm{mL}^{-1}\right)$; (f) medium-dose YHPG group $\left(312.5 \mu \mathrm{g} \cdot \mathrm{mL}^{-1}\right)$; (g) low-dose YHPG group $\left(156 \mu \mathrm{g} \cdot \mathrm{mL}^{-1}\right)$; $(\mathrm{h})$ ephedrine hydrochloride group $\left(62.5 \mu \mathrm{g} \cdot \mathrm{mL}^{-1}\right)$; (i) pseudoephedrine hydrochloride group $\left(62.5 \mu \mathrm{g} \cdot \mathrm{mL}^{-1}\right)$; (j) chlorogenic acid group $\left(31.25 \mu \mathrm{g} \cdot \mathrm{mL}^{-1}\right)$; (k) luteoloside group $\left(250 \mu \mathrm{g} \cdot \mathrm{mL}^{-1}\right)$; (l) emodin group $\left(62.5 \mu \mathrm{g} \cdot \mathrm{mL}^{-1}\right)$.

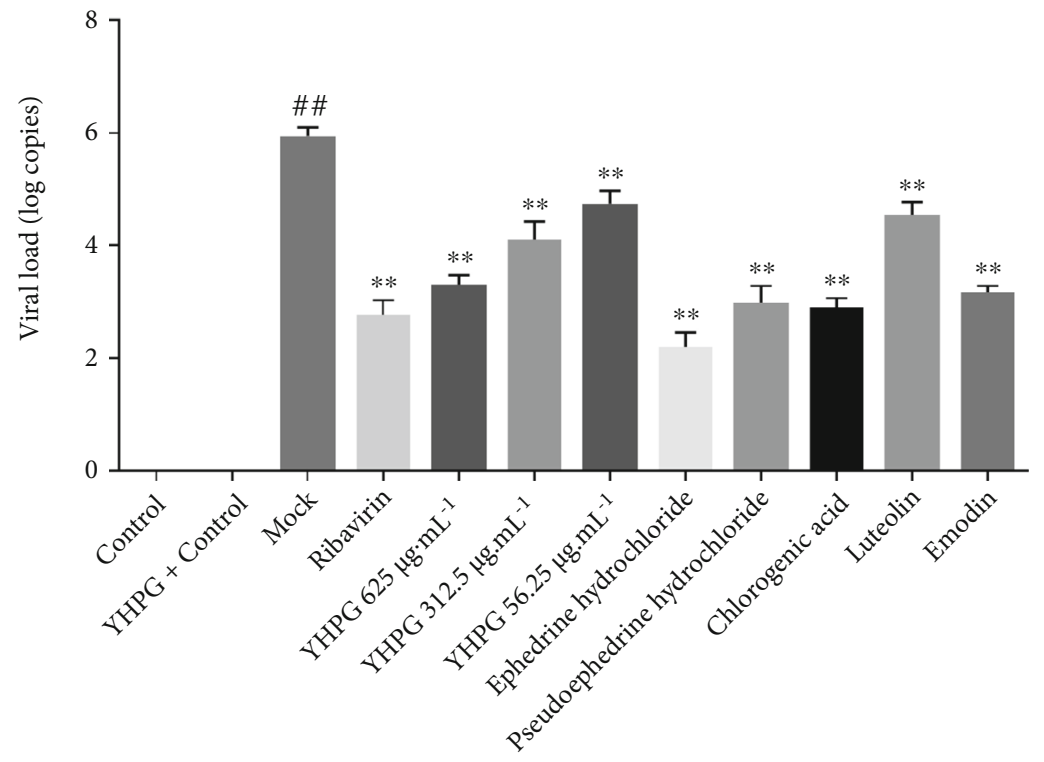

Figure 5: Viral load in H1N1 virus-infected MDCK cells following the treatment of YHPG and the main active components. Compared with the control group, ${ }^{\# \#} P<0.01$; compared with the mock group, ${ }^{* *} P<0.01$.

wind and ventilate the lungs and clear away heat and toxic materials. Pharmacological studies have indicated that Flos Lonicerae Japonicae possesses antibacterial, antiviral, antipyretic, and anti-inflammatory properties and enhances immunity [11]. Glycyrrhizae Radix has anti-inflammatory, antiviral, and antitumor functions [12]. Herba Ephedrae has antioxidant and antiviral functions [13], and Polygoni Cuspidati Rhizoma has antibacterial, antiviral, and antitumor functions $[14,15]$. From the literature, chlorogenic acid, an active component of Flos Lonicerae Japonicae, has shown an inhibitory effect on virus replication [16]. The main component of Glycyrrhizae Radix, glycyrrhizin, may protect mice exposed to a lethal amount of influenza virus through the stimulation of IFN- $\gamma$ production by $\mathrm{T}$ cells and has been reported to inhibit influenza $A$ virus uptake into the cell [17]. Glycyrrhizin concentrations that inhibited H5N1induced proinflammatory gene expression did not affect nat- ural killer cells' cytolytic activity [18]. Furthermore, emodin, an active component of Polygoni Cuspidati Rhizoma, inhibits the replication of influenza virus H1N1 in A549 cells [19]. So, we hypothesize that chlorogenic acid, glycyrrhizin, and emodin may be the active components of YHPG against the influenza virus. However, YHPG is composed of many traditional Chinese medicines and has more complex components. Additional investigations must identify the possible anti-influenza bioactive components in YHPG. Based on preliminary evidence, this study further confirmed that YHPG, within the effective concentration range, has a marked therapeutic effect on the influenza virus, effectively reducing CPE and has protective effects on MDCK cells after influenza virus infection. Simultaneously, we found that the main antiviral components of YHPG were ephedrine hydrochloride, pseudoephedrine hydrochloride, chlorogenic acid, and emodin. 


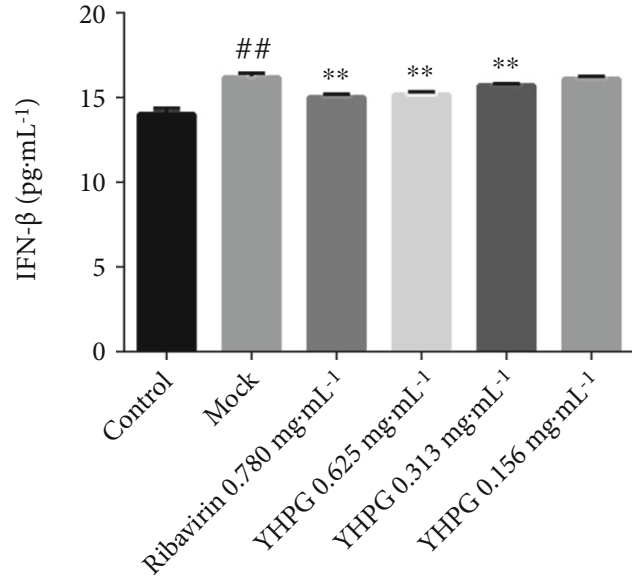

(a)

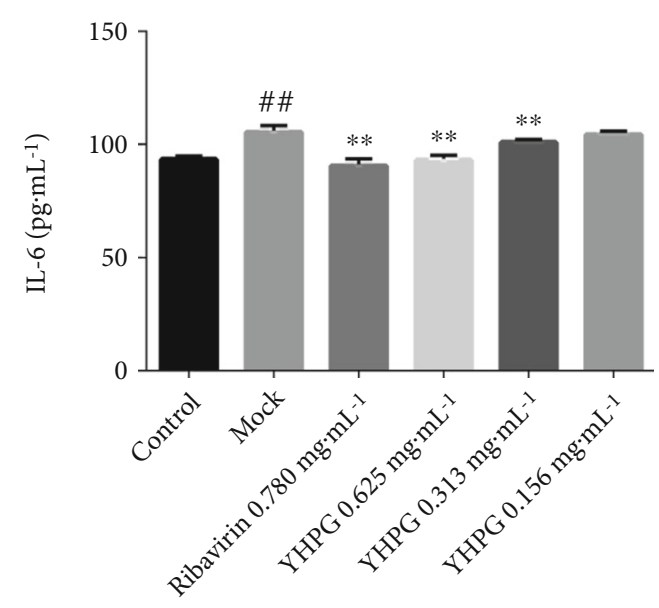

(b)

Figure 6: Effects of YHPG on the levels of IFN- $\beta$ and IL-6 secreted by H1N1 virus-infected MDCK cells $(\bar{x} \pm s, n=9)$. Compared with the control group, ${ }^{\# \#} P<0.01$; compared with the mock group, ${ }^{* *} P<0.01$.

TLRs comprise a group of important pathogen-related pattern recognition receptors (PPRs) [20]. These receptors specifically recognize different pathogen-associated molecular patterns (PAMPs) [21], activate intracellular signaling pathways, mediate corresponding immune responses and induce proinflammatory cytokines, chemokines, and interferons, and have important functions against pathogens.

There are two major antiviral immune pathways mediated by TLRs: MyD88-dependent and MyD88-independent pathways. TLR7 signaling belongs to the MyD88-dependent pathway and is located in the inner body membrane, which can identify the virus single-stranded RNA (ssRNA) [22]. Upon pathogen infection, TLR7 interacts with its corresponding ligands, and the intracellular Toll/interleukin-1 receptor homology (TIR) domain of activated TLR7 binds to and interacts with the carboxyl-terminus of MyD88 [23]. Activated MyD88 then induces the phosphorylation of members of the interleukin-1 receptor-associated kinase (IRAK) family to activate TRAF6 and transmit the signal to MAPK, JNK, and p65 NF- $\kappa$ B [24], ultimately resulting in the secretion of many types of immune-associated cytokines and chemokines for the antiviral response, such as IFN- $\beta$ and IL-6 $[25,26]$. Previous studies have found that the expression of TLR7 was significantly upregulated in immune cells infected with the influenza A virus [27]. Furthermore, TLR7 signaling also induced downstream proinflammatory cytokines [28]. MyD88 is essential for proinflammatory cytokine production [29] and optimal protection against various pathogens, including viruses [30, 31]. TRAF6 has been identified as a signal transducer, resulting in the production of cytokines [32]. JNK is activated during many viral infections [33] and is required for polarized differentiation of $\mathrm{T}$ helper cells into Th1 cells [34]. T cell receptor-activated $\mathrm{p} 38 \alpha$ and $\mathrm{p} 38 \beta$ MAPK are important and redundant positive regulators of $\mathrm{T}$ cell proliferation and inflammatory autoimmunity [35]. The activation of NF- $\kappa \mathrm{B}$, as a marker of the proliferation of influenza virus in host cells [36], is also a key regulator of gene expression of inflammatory factors and plays an important role in the pathogenesis of antiinfluenza virus infection [37].
Previous experiments have suggested that the pathogenesis and severity of influenza virus infection are associated with various levels of IFN- $\beta$ and IL-6 [38]. Studies have shown that increased proinflammatory cytokines and mononuclear factors (including IL-6) were observed in the serum of infected patients and in infected mice's lungs, which associated with the pathogenesis and severity of influenza virus infection [39-41]. IFN- $\beta$, as an important cytokine, is involved in the body's immune regulation and could enhance natural killer cells (NK cells), macrophages, and T lymphocyte activity, thus improving the antivirus ability [42]. It also plays an important role in antivirus and immune regulation by inducing antiviral proteins' expression.

Our study showed a significant upregulation of the content of IFN- $\beta$ and IL- 6 in cell supernatants and the levels of TLR7, MyD88, TRAF6, JNK, p38 MAPK, and p65 NF- $\kappa \mathrm{B}$ gene expression after MDCK cells were infected with influenza virus $(P<0.01)$, suggesting that the influenza virus infection activated the TLR7-MyD88 pathway, induced an inflammatory reaction, and caused the production of cytokines and chemokines in MDCK cells. The content of IFN$\beta$ and IL- 6 in the cell supernatant and expression of cellular TLR7, MyD88, TRAF6, JNK, p38 MAPK, and p65 NF- $\kappa$ B genes significantly decreased after influenza virus-infected MDCK cells were treated with high and medium doses of YHPG $(P<0.01, P<0.05)$. CPE was also effectively reduced. Furthermore, compared with the mock group, MDCK treated with YHPG showed a dose-dependent manner. These results indicate that YHPG has a therapeutic effect on MDCK cells infected with the influenza virus. The mechanism of action may be associated with inhibition of the activation of TLR7/MyD88 signaling, thus inhibiting the secretion of IFN- $\beta$ and IL- 6 .

Nonetheless, there are many subtypes of TLRs, and previous studies have indicated that YHPG could also exert antiviral function by inhibiting the activation of the TLR4/ MyD88 pathway. The determination of whether YHPG exerts synergistic antiviral effects by regulating other subtypes requires further in-depth studies. Furthermore, it was 


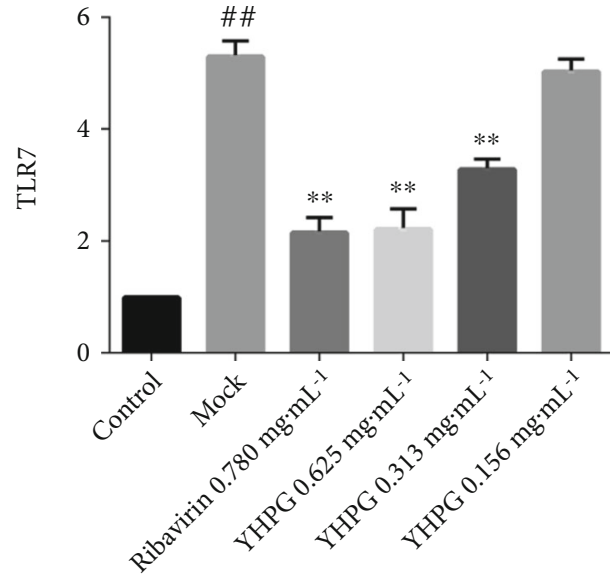

(a)

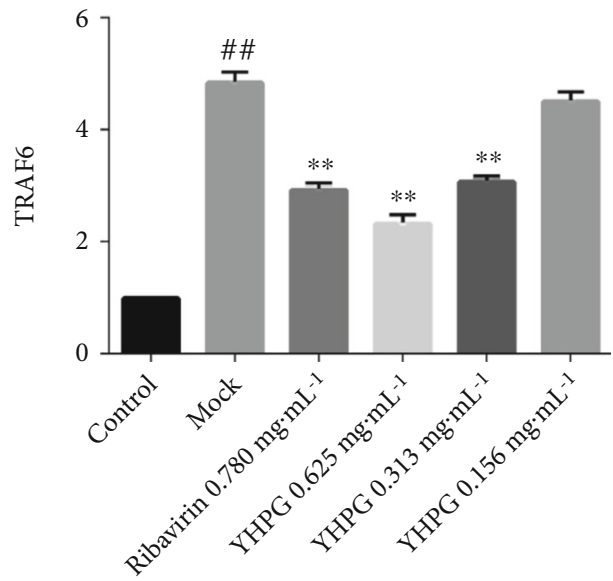

(c)

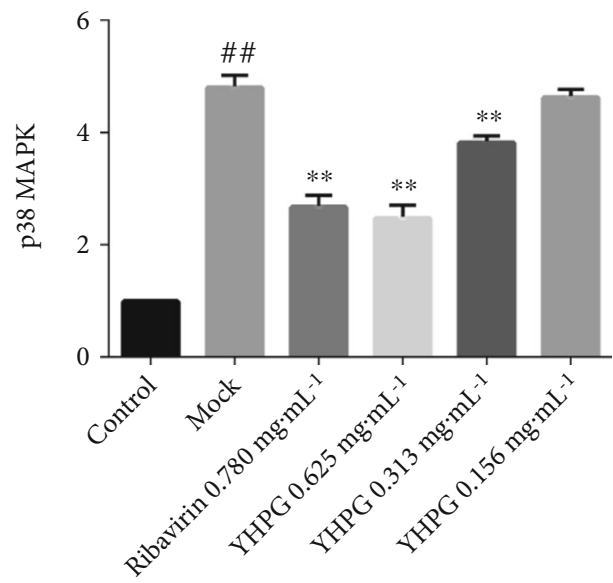

(e)

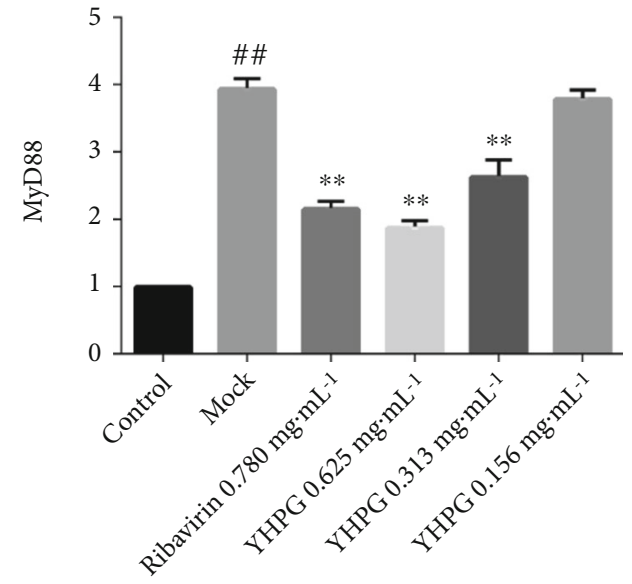

(b)

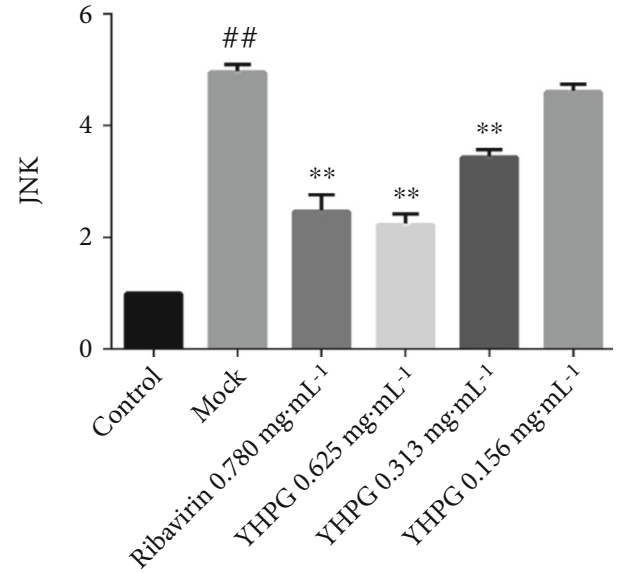

(d)

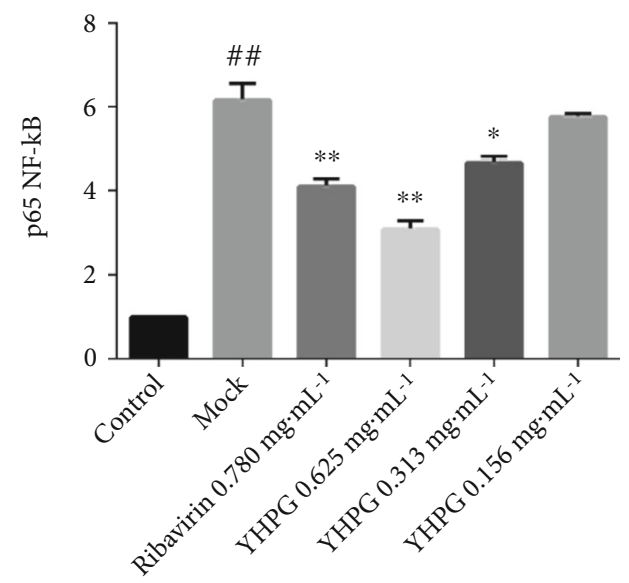

(f)

FIGURE 7: Effects of YHPG on the RNA expression of related genes in H1N1 virus-infected MDCK cells $(\bar{x} \pm s, n=9)$. Compared with the control group, ${ }^{\# \#} P<0.01$; compared with the mock group, ${ }^{*} P<0.05$ and ${ }^{* *} P<0.01$.

reported that the tripartite motif-containing 29 (TRIM29) plays a critical role in host defense against influenza virus infection, a key adaptor in both the IRF-mediated type-Iinterferon production and the NF- $\kappa \mathrm{B}$-mediated proinflammatory signaling pathways [43]. Our previous study found that YHPG significantly downregulated the mRNA expres- sion of IRF7 and the protein expressions of the phosphorylated forms of IRF3 in RAW264.7 cells [44, 45]. Therefore, TRIM29 will be another powerful biomarker for our indepth and meticulous future studies.

In conclusion, this research examined the anti-influenza effect of YHPG in vitro, and the results indicated that YHPG 
and its main active components (ephedrine hydrochloride, pseudoephedrine hydrochloride, chlorogenic acid, and emodin) exerted antiviral function by inhibiting virus-related gene expression. A therapeutic effect of YHPG on MDCK cells infected with the influenza virus was observed. These results provide a theoretical basis for further clinical application of YHPG. In subsequent studies, we will further investigate the synergistic effect and compatibility mechanism of increasing effectiveness of the main active components in YHPG.

\section{Data Availability}

The data used to support the findings of this study are available from the corresponding author upon request.

\section{Conflicts of Interest}

The authors declare that they have no conflicts of interest.

\section{Authors' Contributions}

HW and JY conceived the idea and designed the study. TC, $\mathrm{HZ}$ and $\mathrm{HD}$ participated in the experimental study and wrote the manuscript. HD, JZ, and XT performed the cell studies. YL and YF participated in the figure preparation. TC, YY and JW participated in the data collection and statistical analysis. $\mathrm{YH}$ and $\mathrm{HW}$ revised the manuscript. All authors read and approved the final manuscript. Tianhang Chen and Haixia Du are regarded as co-first authors.

\section{Acknowledgments}

This work was financially supported by the National Natural Science Foundation of China (No. 81930111), Key Laboratory of TCM Encephalopathy of Zhejiang Province (grant no. 2020E10012), and Key R\&D Projects in Zhejiang Province (grant no. 2020C03052). We thank Professor Yi-yu Lu from the Zhejiang Center for Disease Control and Prevention for the technical help in this work.

\section{Supplementary Materials}

Figure 1: 2D HPLC chromatograms of eight effective components in YHPG at $210 \mathrm{~nm}$. 1: L-ephedrine; 2: Dpseudoephedrine; 3: chlorogenic acid; 4: amygdalin; 5: puerarin; 6: polydatin; 7: glycyrrhizic acid; 8: emodin. (Supplementary Materials)

\section{References}

[1] M. Bassetti, N. Castaldo, and A. Carnelutti, "Neuraminidase inhibitors as a strategy for influenza treatment: pros, cons and future perspectives," Expert Opinion on Pharmacotherapy, vol. 20, no. 14, pp. 1711-1718, 2019.

[2] D. Radosevic, M. Sencanski, V. Perovic et al., "Virtual screen for repurposing of drugs for candidate influenza a M2 ionchannel inhibitors," Frontiers in Cellular and Infection Microbiology, vol. 9, p. 67, 2019.
[3] H. Ti, "Phytochemical profiles and their anti-inflammatory responses against influenza from traditional Chinese medicine or herbs," Mini Reviews in Medicinal Chemistry, vol. 20, no. 20, pp. 2153-2164, 2020.

[4] X. Q. Peng, H. F. Zhou, Y. Y. Zhang, J. H. Yang, H. T. Wan, and Y. He, "Antiviral effects of Yinhuapinggan granule against influenza virus infection in the ICR mice model," Journal of Natural Medicines, vol. 70, no. 1, pp. 75-88, 2016.

[5] Y. He, H. T. Wan, H. F. Zhou et al., "A randomized, doubleblind, parallel-controlled, multi-center clinical study on the safety and effectiveness of Qingjiexuantou Feiwei recipe in the treatment of exogenous fever syndrome," Chinese Journal of Traditional Chinese Medicine, vol. 34, no. 12, pp. 5972-5977, 2020.

[6] H. T. Wan, Y. He, H. F. Zhou et al., "A safety and effectiveness research of Yinhua Pinggan granule of Qingjie Xuantou lung defense prescription for treatment of patients with upper respiratory tract infection accompanied by syndrome of pathogen stagnated in lung-defense phase: a randomized double blinded, positive drug parallel controlled and multicentric clinical trial," Chinese Journal of Integrated Traditional and Western Medicine in Intensive and Critical Care, vol. 24, no. 6, pp. 602-607, 2017.

[7] H. Q. Peng, Z. M. Xu, H. T. Wan, and D. J. Yu, "Inhibition of Jinpinggan granules on influenza virus," Zhejiang Journal of Traditional Chinese Medicine, vol. 40, no. 2, pp. 87-87, 2005.

[8] X. Q. Peng, Y. He, H. F. Zhou et al., “Anti-H1N1 influenza virus effect of Yinhua Pinggan granules," Chinese Journal of Traditional Chinese Medicine, vol. 40, no. 19, pp. 3845-3850, 2015.

[9] Y. He, D. J. Yu, Y. Y. Zhang, J. H. Yang, H. F. Zhou, and H. T. Wan, "Experimental study on antitussive effect of Yinhua Pinggan granules," Chinese Archives of Traditional Chinese Medicine, vol. 32, no. 9, pp. 2060-2061, 2014.

[10] H. T. Wan, D. J. Yu, Y. Lei, H. B. Bai, J. H. Yang, and X. D. Bie, "Experimental study on the anti-inflammatory and analgesic effects of Jinpinggan granules," Pharmacology and Clinics of Chinese Medicine, vol. 18, no. 3, pp. 39-40, 2002.

[11] A. Q. Zeng, H. Hua, C. R. Chen et al., "Study on antiinflammatory pharmacological action of honeysuckle and Lonicera japonica," Chinese Journal of Traditional Chinese Medicine, vol. 45, no. 16, pp. 3938-3944, 2020.

[12] Y. X. Jiang, Y. Y. Dai, Y. F. Pan et al., “Total flavonoids from Radix Glycyrrhiza exert anti-inflammatory and antitumorigenic effects by inactivating iNOS signaling pathways," Evidence-based Complementary and Alternative Medicine, vol. 2018, Article ID 6714282, 2018.

[13] J. L. Li, L. Fang, Y. Q. Zhang, X. Wang, and Q. D. Zhang, "Advances in chemical constituents and pharmacological activities of ephedra," Journal of modern chinese medicine, vol. 14, no. 7, pp. 21-27, 2012.

[14] W. H. Hu, G. K. Chan, J. S. Lou et al., "The extract of Polygoni Cuspidati Rhizoma et Radix suppresses the vascular endothelial growth factor-induced angiogenesis," Phytomedicine, vol. 42, pp. 135-143, 2018.

[15] I. Nawrot-Hadzik, J. Hadzik, M. Fleischer et al., "Chemical composition of east Asian invasive knotweeds, their cytotoxicity and antimicrobial efficacy against cariogenic pathogens: an in-vitro study," Medical Science Monitor, vol. 25, pp. 32793287, 2019. 
[16] V. Sinisi, A. Stevaert, F. Berti et al., "Chlorogenic compounds from coffee beans exert activity against respiratory viruses," Planta Medica, vol. 83, no. 7, pp. 615-623, 2017.

[17] X. Xu, L. Gong, B. Wang et al., "Glycyrrhizin attenuates Salmonella enterica Serovar Typhimurium infection: new insights into its protective mechanism," Frontiers in Immunology, vol. 9, p. 2321, 2018.

[18] A. I. Fayrushina, L. A. Baltina Jr., L. A. Baltina, N. I. Konovalova, P. A. Petrova, and M. Y. Eropkin, "Synthesis and antiviral activity of novel glycyrrhizic acid conjugates with D-amino acid esters," Russian Journal of Bioorganic Chemistry, vol. 43, no. 4, pp. 456-462, 2017.

[19] C. J. Lin, H. J. Lin, T. H. Chen et al., "Polygonum cuspidatum and its active components inhibit replication of the influenza virus through toll-like receptor 9-induced interferon beta expression," PLoS One, vol. 10, no. 2, article e0117602, 2015.

[20] X. Lv, H. Wang, A. Su, S. Xu, and Y. Chu, "Herpes simplex virus type 2 infection triggers AP-1 transcription activity through TLR4 signaling in genital epithelial cells," Virology Journal, vol. 15, no. 1, p. 173, 2018.

[21] J. Zindel and P. Kubes, "DAMPs, PAMPs, and LAMPs in immunity and sterile inflammation," Annual Review of Pathology, vol. 15, pp. 493-518, 2020.

[22] K. Poulas, K. Farsalinos, and C. Zanidis, "Activation of TLR7 and innate immunity as an efficient method against COVID19 pandemic: imiquimod as a potential therapy," Frontiers in Immunology, vol. 11, p. 1373, 2020.

[23] K. V. Korneev, K. N. Atretkhany, M. S. Drutskaya, S. I. Grivennikov, D. V. Kuprash, and S. A. Nedospasov, "TLR-signaling and proinflammatory cytokines as drivers of tumorigenesis," Cytokine, vol. 89, pp. 127-135, 2017.

[24] J. P. Dai, Q. W. Wang, Y. Su et al., "Oxymatrine inhibits influenza a virus replication and inflammation via TLR4, p38 MAPK and NF- $\kappa$ B pathways," International Journal of Molecular Sciences, vol. 19, no. 4, 2018.

[25] T. Betakova, A. Kostrabova, V. Lachova, and L. Turianova, "Cytokines induced during influenza virus infection," Current Pharmaceutical Design, vol. 23, no. 18, pp. 2616-2622, 2017.

[26] T. L. Chao, S. Y. Gu, P. H. Lin, Y. T. Chou, T. Y. Ling, and S. Y. Chang, "Characterization of influenza A virus infection in mouse pulmonary stem/progenitor cells," Frontiers in Microbiology, vol. 10, p. 2942, 2019.

[27] Y. Shi, H. Xu, Y. Xiao et al., "Gegen Qinlian decoction downregulates the TLR7 signalling pathway to control influenza A virus infection," Biomedicine \& Pharmacotherapy, vol. 121, article 109471, 2020.

[28] A. T. Bender, E. Tzvetkov, A. Pereira et al., "TLR7 and TLR8 differentially activate the IRF and NF- $\kappa$ B pathways in specific cell types to promote inflammation," Immunohorizons, vol. 4, no. 2, pp. 93-107, 2020.

[29] M. Yamamoto, S. Sato, H. Hemmi et al., "TRAM is specifically involved in the toll-like receptor 4-mediated MyD88independent signaling pathway," Nature Immunology, vol. 4, no. 11, pp. 1144-1150, 2003.

[30] R. Zhang, X. Ai, Y. Duan et al., "Kaempferol ameliorates H9N2 swine influenza virus-induced acute lung injury by inactivation of TLR4/MyD88-mediated NF- $\kappa$ B and MAPK signaling pathways," Biomedicine \& Pharmacotherapy, vol. 89, pp. 660-672, 2017.

[31] S. U. Seo, H. J. Kwon, J. H. Song et al., "MyD88 signaling is indispensable for primary influenza A virus infection but dis- pensable for secondary infection," Journal of Virology, vol. 84, no. 24, pp. 12713-12722, 2010.

[32] Y. Min, M. J. Kim, S. Lee, E. Chun, and K. Y. Lee, "Inhibition of TRAF6 ubiquitin-ligase activity by PRDX1 leads to inhibition of NFKB activation and autophagy activation," Autophagy, vol. 14, no. 8, pp. 1347-1358, 2018.

[33] J. Dai, L. Gu, Y. Su et al., "Inhibition of curcumin on influenza A virus infection and influenzal pneumonia via oxidative stress, TLR2/4, p38/JNK MAPK and NF- $\kappa$ B pathways," International Immunopharmacology, vol. 54, pp. 177-187, 2018.

[34] Y. Kobayashi, N. Kurose, X. Guo et al., "The potential role of follicular helper $\mathrm{T}$ cells and helper T cells type 1 in Warthin tumour," Pathology, Research and Practice, vol. 220, article 153386, 2021.

[35] L. Jirmanova, M. L. Giardino Torchia, N. D. Sarma, P. R. Mittelstadt, and J. D. Ashwell, "Lack of the T cell-specific alternative p38 activation pathway reduces autoimmunity and inflammation," Blood, vol. 118, no. 12, pp. 3280-3289, 2011.

[36] J. P. Dai, Q. W. Wang, Y. Su et al., "Emodin inhibition of influenza A virus replication and influenza viral pneumonia via the Nrf2, TLR4, p38/JNK and NF-kappaB pathways," Molecules, vol. 22, no. 10, 2017.

[37] M. Zhong, H. Q. Wang, H. Y. Yan, S. Wu, Z. Y. Gu, and Y. H. $\mathrm{Li}$, "Santin inhibits influenza A virus replication through regulating MAPKs and NF- $\kappa$ B pathways," Journal of Asian Natural Products Research, vol. 21, no. 12, article 10.1080/ 10286020.2018.1520221, pp. 1205-1214, 2019.

[38] P. P. Lamichhane and A. E. Samarasinghe, "The role of innate leukocytes during influenza virus infection," Journal of Immunology Research, vol. 2019, Article ID 8028725, 2019.

[39] S. G. Paquette, D. Banner, Z. Zhao et al., "Interleukin-6 is a potential biomarker for severe pandemic H1N1 influenza A infection," PLoS One, vol. 7, no. 6, article e38214, 2012.

[40] M. Thomas, R. S. Mani, M. Philip et al., "Proinflammatory chemokines are major mediators of exuberant immune response associated with influenza A (H1N1) pdm09 virus infection," Journal of Medical Virology, vol. 89, no. 8, pp. 1373-1381, 2017.

[41] S. Liu, R. Yan, B. Chen et al., "Influenza virus-induced robust expression of SOCS3 contributes to excessive production of IL-6," Frontiers in Immunology, vol. 10, p. 1843, 2019.

[42] K. Miyauchi, "Helper T cell responses to respiratory viruses in the lung: development, virus suppression, and pathogenesis," Viral immunology, vol. 30, no. 6, pp. 421-430, 2017.

[43] J. Xing, L. Weng, B. Yuan et al., "Identification of a role for TRIM29 in the control of innate immunity in the respiratory tract," Nature Immunology, vol. 17, no. 12, pp. 1373-1380, 2016.

[44] H. X. Du, H. T. Wan, Y. He, J. H. Yang, Y. Y. Lu, and H. F. Zhou, "In vitro anti-H1N1 influenza virus effect of Yinhua Pinggan granules," Chinese Medicine Journal, vol. 58, no. 23, pp. 2039-2044, 2017.

[45] H. X. Du, H. F. Zhou, H. F. Wan et al., "Antiviral effects and mechanisms of Yinhuapinggan granule against H1N1 influenza virus infection in RAW264.7 cells," Inflammopharmacology, vol. 26, no. 6, pp. 1455-1467, 2018. 